\title{
Improving quality of care for family planning services in Uganda
}

Joel Okullo

Quinto Okello

Harriet Birungi

Population Council

Ian Askew

Population Council

Barbara Janowitz

See next page for additional authors

Follow this and additional works at: https://knowledgecommons.popcouncil.org/departments_sbsr-rh

Part of the Demography, Population, and Ecology Commons, International Public Health Commons, Maternal and Child Health Commons, and the Public Health Education and Promotion Commons How does access to this work benefit you? Let us know!

\section{Recommended Citation}

Okullo, Joel, Quinto Okello, Harriet Birungi, lan Askew, Barbara Janowitz, Carmen Cuthbertson, and Florence Ebanyat. 2003. "Improving quality of care for family planning services in Uganda," FRONTIERS Final Report. Washington, DC: Population Council. 


\section{Authors}

Joel Okullo, Quinto Okello, Harriet Birungi, Ian Askew, Barbara Janowitz, Carmen Cuthbertson, and Florence Ebanyat 


\section{Improving Quality of Care for Family Planning Services in Uganda}

September 2003

Regional Centre for Quality of Health Care

Institute of Public Health, Makerere University

Joel Okullo

Quinto Okello

Frontiers in Reproductive Health

Harriet Birungi (Population Council)

Ian Askew (Population Council)

Barbara Janowitz (Family Health International)

Carmen Cuthbertson (Family Health International)

Reproductive Health Division, Ministry of Health

Florence Ebanyat

\section{Delivery of Improved Services for Health (DISH II) Project}

This study was funded by the U.S. AGENCY FOR INTERNATIONAL DEVELOPMENT (USAID) under the terms of FRONTIERS Cooperative Agreement Number HRN-A-00-98-00012-00 and Population Council subagreement AI00.64A. The opinions expressed herein are those of the authors and do not necessarily reflect the view of USAID. 


\section{Executive Summary}

The Regional Centre for Quality of Health Care at Makerere University, in collaboration with the Delivery of Improved Services for Health II (DISH II) Project, the Ministry of Health of Uganda, and the Population Council's FRONTIERS Program, conducted an Operations Research project to help the Ministry of Health improve the quality of family planning services with the aim of helping couples better attain their reproductive goals. The study developed a package of interventions that sought to increase the readiness of clinics to offer basic family planning services, to improve provider motivation, and to empower clients to request quality services. The project then tested the feasibility of implementing these interventions, and evaluated their effect on the quality of client-provider interactions.

The study covered four districts, and within each district 10 health centres at level III and IV that offer both curative and preventive services including family planning were included. Two of the districts were randomly assigned to an experimental group (Kamuli and Luweero) and two to be the comparison group (Masaka and Masindi). A facility audit generated data on the functioning of subsystems for providing family planning services in all 40 clinics and seven 'readiness' interventions were then introduced in all clinics with the intention of bringing all of the clinics to a comparable level of readiness to offer basic family planning services. Thereafter, a package of three 'study' interventions was introduced through the Yellow Star Programme (YSP) in the 20 experimental clinics only; these interventions specifically targeted provider motivation and client empowerment. Baseline and postintervention data were collected using a facility audit, interviews with providers and clients, observation of client-provider interactions, and a time motion study.

The package of readiness interventions did somewhat increase the functioning of basic family planning services in all clinics and to a comparable level, but these improvements were not significantly different than the baseline levels. The interventions had little or no effect on provider knowledge about family planning methods, or on their ability to gather relevant information from clients. The pattern of provider time use remained unaffected, with up to 40 percent of their time in the clinic spent unproductively. Dissemination of provider guidelines and the Health Management Information System (HMIS) was limited to a few facilities. Supervision improved significantly, however, with supervisors being more thorough, visits being more frequent, and increased appreciation by supervisees' of the benefits of supervision. The study interventions (i.e. the Yellow Star Programme) did significantly improve providers' job satisfaction and motivation, although there was no appreciable change in client empowerment.

The study interventions did create an immediate effect on quality of care in the clinics, with an increasing number of clinics attaining most of the basic quality standards set by the Yellow Star Programme. Moreover, the quality of client-provider interactions also improved significantly after the interventions. However, there was only a moderately significant difference between the experimental and comparison groups during the post-intervention survey, suggesting a limited effect of the study interventions on client-provider interactions. In conclusion, the study provided empirical evidence that quality of care can be improved by a combination of interventions targeting system, provider and client levels. In addition, introducing non-monetary incentives can improve provider motivation. The Yellow Star Programme showed potential in improving quality of care, and perhaps its impact will be more pronounced over time. 


\section{Table Of Contents}

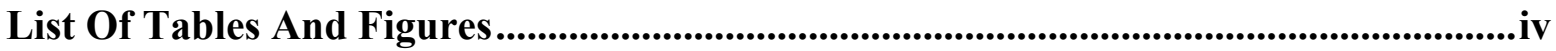

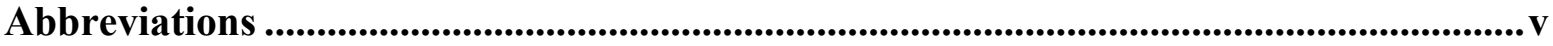

Acknowledgements ..................................................................................................................................vi

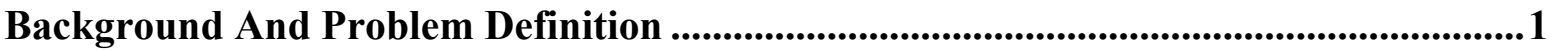

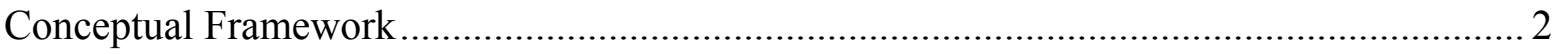

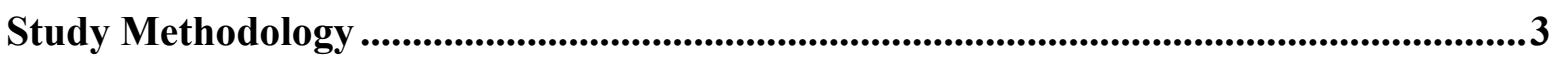

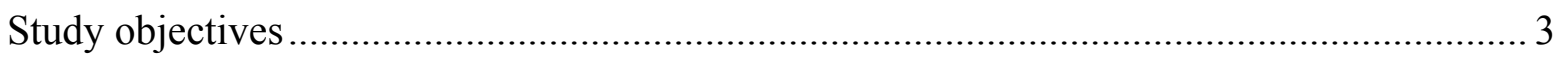

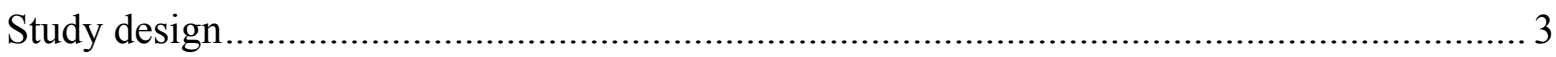

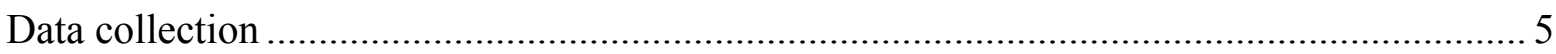

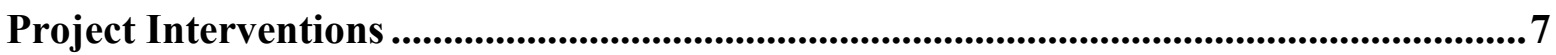

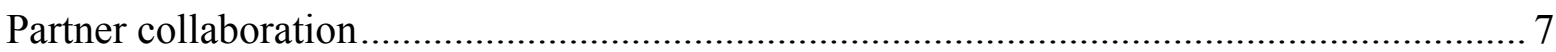

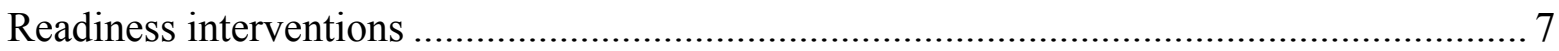

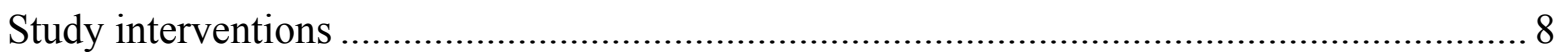

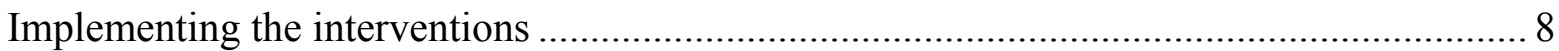

Updating and dissemination of Reproductive Health (RH) policy guidelines and service

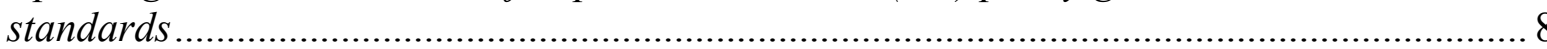

Ensuring the availability of minimum equipment and supplies required to offer Depo

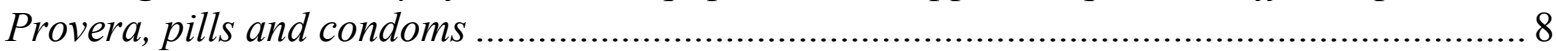

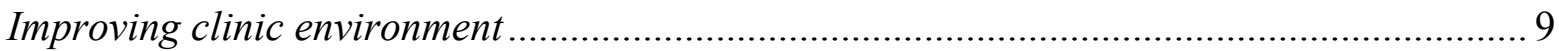

Improving Health Management Information System (HMIS) .............................................. 9

Improving the availability of appropriate FP IEC materials ............................................... 9

Building the capacity of district and sub-district supervisors for facilitative supervision...... 9

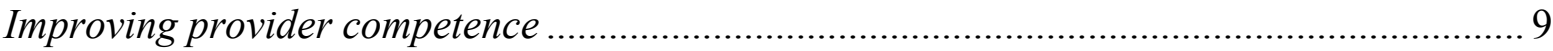

Building capacity of DHMTs and SDHMTs for strategic planning and goal setting, improving provider motivation, and increasing clients awareness of and demand for quality services 


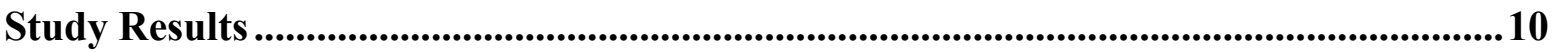

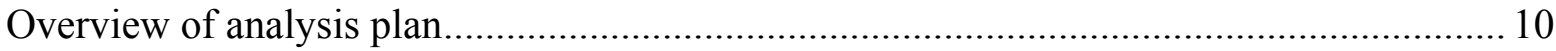

Readiness to offer quality family planning services ..................................................... 10

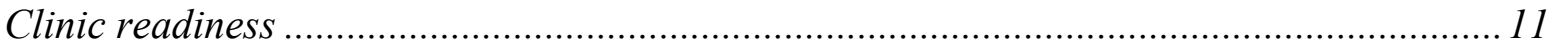

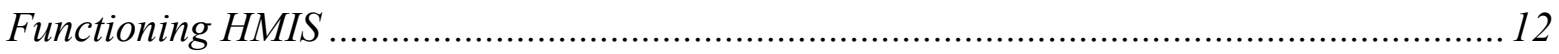

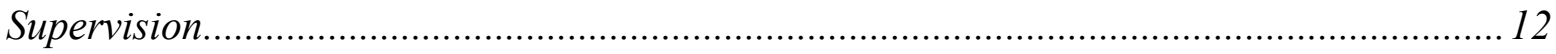

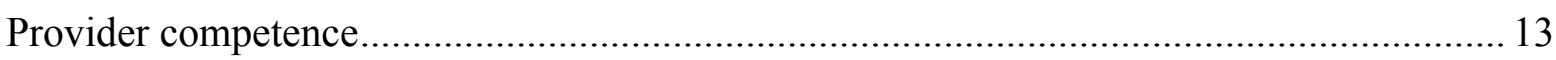

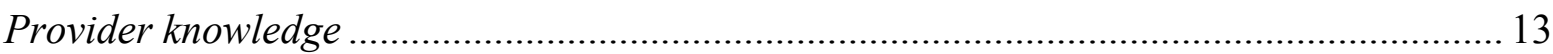

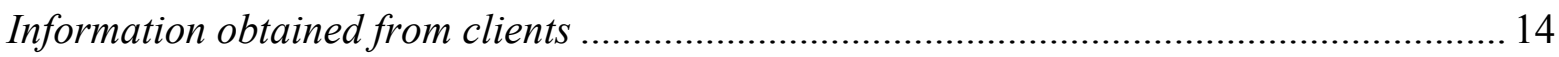

Compliance with infection control guidelines .............................................................. 15

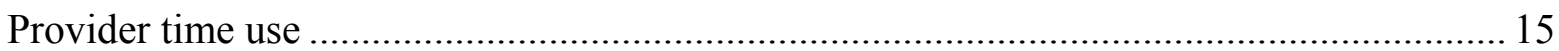

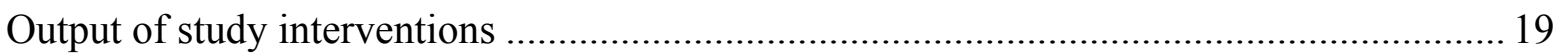

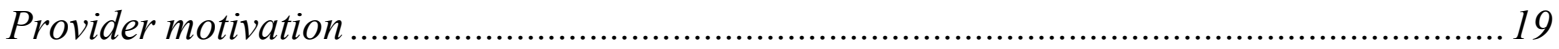

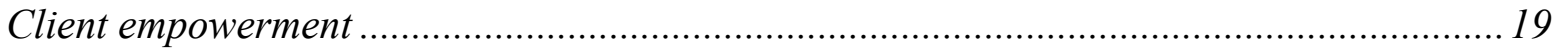

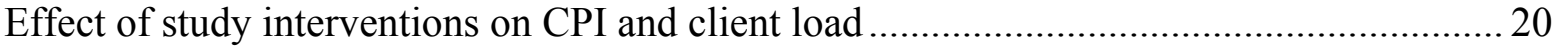

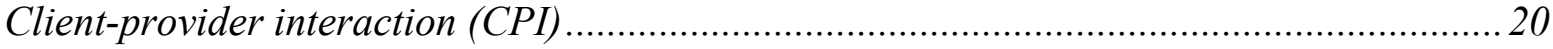

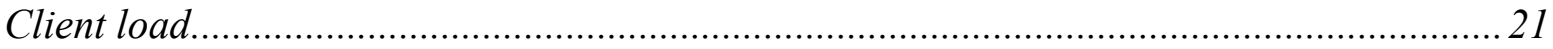

Conclusions and recommendations ...........................................................................................22

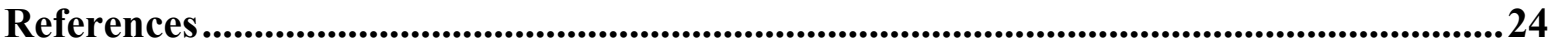

Annex I: Infrastructure, staffing and functions of HC III \& IV ...................................25

Annex II: Summary of implementation of QOC interventions .........................................25

ANNEX III: Basic Standards for Quality of Care in the Yellow Star Programme.......27 


\section{List Of Tables And Figures}

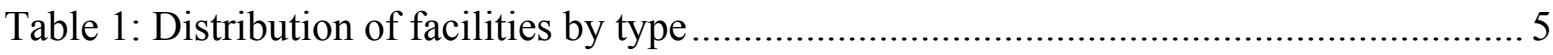

Table 2: Sample sizes by data collection method ............................................................. 5

Table 3: Sample sizes by type of client ..................................................................... 6

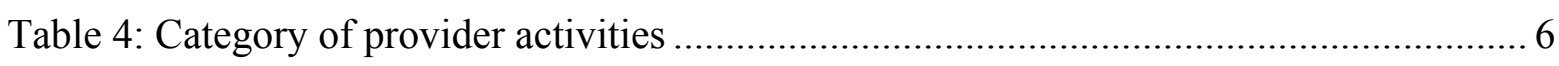

Table 5: Clinic readiness......................................................... 11

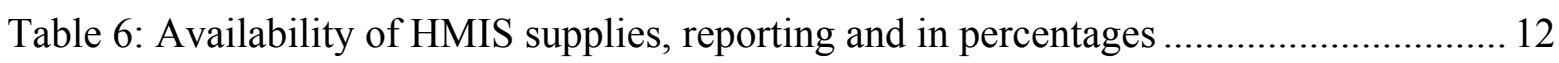

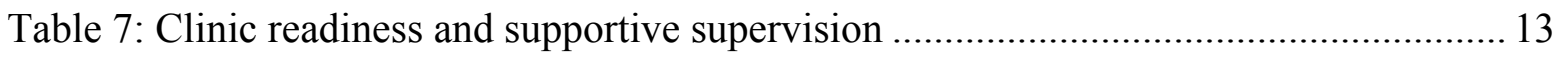

Table 8: Provider knowledge scores of different contraceptive methods............................. 14

Table 9: Mean scores of essential information elicited from new clients ........................... 14

Table 10: Percentage of injectable client interactions in which the provider complied with

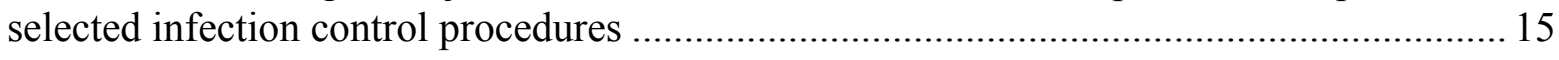

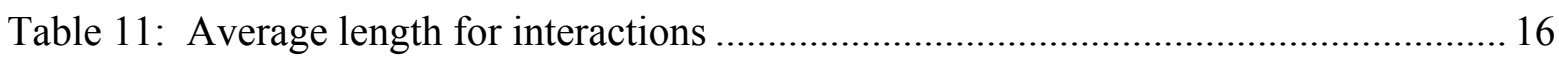

Table 12: Average number of interactions by type of service per observation day .............. 16

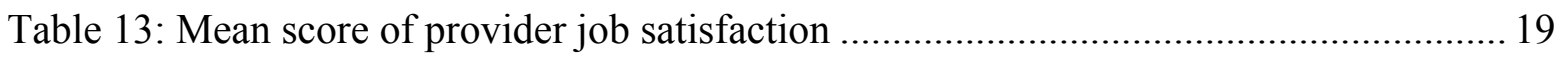

Table 14: Percentage of clients who did not feel shy and asked questions ........................ 19

Table 15: The quality of client provider interactions .................................................... 20

Table 16: Average number of clinic visits in 12 months by type of service ........................ 21

Figure 1: Distribution of time spent with each type of client by group............................. 17

Figure 2: Percentage distribution of how providers spend their day .................................. 18 


\section{Abbreviations}

AIDS

ANOVA

CPI

DHMT

FP

DISH

HIV

HMIS

HSD

HSDMT

ICPD

IPC

$\mathrm{MOH}$

NSG

QAD

QIQ

QOC

RCQHC

$\mathrm{RH}$

RHD

SS

STI

UDHS

USAID

YSP
Acquired Immune Deficiency Syndrome

Analysis of Variance

Client Provider interaction

District Health Management Team

Family Planning

Delivery of Improved Services for Health

Human Immuno-suppressive Virus

Health Management Information System

Health Sub-District

Health Sub-District Management Team

International Conference on Population and Development

Interpersonal Communication

Ministry of Health

National Supervision Guidelines

Quality Assurance Division

Quick Investigation of Quality

Quality of Care

Regional Centre for Quality of Health Care

Reproductive Health

Reproductive Health Division

Supportive Supervision

Sexually Transmitted Infections

Uganda Demographic and Health Survey

United States Agency for International Development

Yellow Star Programme 


\section{Acknowledgements}

Special mention must be made of the excellent collaboration we had with local partners: DISH II project, the MOH, Uganda, and District Directors of Health Services at all stages of the project. The study benefited immensely from the technical support provided by Dr. Ndugga Maggwa and Dr. Nancy Williamson of Family Health International.

We are greatly indebted to the researchers and Team Leaders who sacrificed so much in the field to collect data for this study. In the same vein we thank those clients who agreed to participate in the study and spared time to answer interview questions. We wish also to thank the data analysts and entry clerks for their input in processing the raw data.

We wish to acknowledge the various comments and inputs we received from the global collaborating partners: Dr. Susan Adamchak, the FRONTIERS Global Agenda Coordinator; local collaborators; and RCQHC technical staff. These inputs were invaluable in shaping this report. 


\section{Background And Problem Definition}

Uganda is characterised by a context of high fertility rates, low contraceptive prevalence, high unmet need for family planning (FP) services, and declining utilization of government facilities as a source for FP services. As shown in the most recent Ugandan Demographic and Health Survey (UDHS), national fertility levels have remained stationery at 6.9 children per woman since 1995 (Uganda Bureau of Statistics and ORC Macro, 2001). The contraceptive prevalence rate among married women is 23 percent, although only 18 percent use modern methods. Thirty-five percent of married women have an unmet need for family planning services, 21 percent for spacing and 14 percent for limiting. Unplanned pregnancies are still very common - one in four births during the five years prior to the 2000 - 2001 UDHS were reported as mistimed (mostly wanted later), and 15 percent were not wanted at all.

A significant shift in the source of family planning services was noted by the 2000-2001 UDHS. Public sources declined from 47 percent of all users in 1995 to 36 percent in 2000 2001. The proportions of pill and injectable users who obtain their method from a government facility has declined, from 39 percent to 31 percent and from 61 percent to 47 percent, respectively, although public sources continue to provide the majority of female sterilizations. The negative attitude of de-motivated health workers was cited as a factor discouraging users from attending government facilities. Part of the explanation for this may be found in a 'Quick Investigation of Quality' (QIQ) survey undertaken by the USAIDsupported Delivery of Improved Service for Health (DISH) II Project in 1999 (Bessinger et $a l, 2000)$. This survey covered 10 districts in which the DISH Project had been working and found client-provider interactions, history taking and screening, infection prevention and client education were weak. This not only made clinics unattractive to potential clients (thereby maintaining the fairly low level of contraceptive prevalence generally), but also exacerbated the already high levels of contraceptive discontinuation.

Given this situation, there is increasing concern by the Reproductive Health Division at the Ministry of Health (MOH) about the quality of family planning services in Uganda. There is clearly a growing need to introduce a package of interventions that explicitly seek to motivate improved service provider performance, ensure high quality of client-provider interactions, and strengthen essential support systems. To assist the $\mathrm{MOH}$ to address this issue, the Regional Centre for Quality of Health Care (RCQHC) at Makerere University, with technical and financial support from the Population Council's FRONTIERS Programme, joined with the DISH II project to undertake an operations research study that developed such a package of interventions and tested their effect on the quality of family planning services. (Similar studies were undertaken simultaneously in Egypt and Peru as part of FRONTIERS' Global Agenda on improving quality of family planning care.) The major question for this study was whether introducing a package of systems-based, provider-oriented, and client-centered interventions could make measurable improvements in targeted aspects of quality of care. 


\section{Conceptual Framework}

The literature on quality of family planning services suggests that probably the most crucial component, in terms of its effect on clients' family planning behavior and satisfaction, is the interaction between providers and clients during women's visits to clinics. The 'clientprovider interaction' (CPI) encompasses both the process (how clients are treated and whether they actively participate) and the content (what they are told or not told, technical competence, accuracy of information, provision of essential information) of a consultation. Poor client-provider interaction, therefore, can lead to clients not having essential information to choose an appropriate method; not getting the method they want; not learning what they need to know about how to use the method or how to cope with side effects; not being aware that they can switch methods if their current one is unsatisfactory; not being satisfied with their method; and ultimately, not achieving their fertility goals, due to contraceptive failure or discontinuation. Although no specific data are available for Uganda on contraceptive continuation rates, data from other countries in the region indicate that between one-third and one-half of pill acceptors discontinue within the first year, and even higher discontinuation rates are found for other user-dependent methods such as injectables and barrier methods.

Improving the quality of services that women receive is expected to have an impact on women's satisfaction with the services, on their continued use and, ultimately, on their ability to achieve their fertility goals or reproductive intentions. Surprisingly, however, there is little empirical evidence of either whether this expectation is correct, or how best to improve service quality within reproductive health programmes so that these impacts can be achieved.

The expectation that improving quality of services will lead to better reproductive health outcomes has encouraged the $\mathrm{MOH}$ to look for ways to actively strengthen its reproductive health programme. Decentralization of services is a major component of the current health sector reforms in Uganda, and has led to a localization of decision-making, budgeting, and planning. This transfer of authority sets the stage for a more focused response to community needs by local providers and has the potential to improve the quality of services provided to clients. Therefore, as the $\mathrm{MOH}$ decentralizes health services to the sub-district level, it would like to ensure that such leadership exists at these levels.

The $\mathrm{MOH}$ is interested in learning more about alternative programmatic interventions for achieving its goal of better quality family planning services. It has already identified some issues that need to be addressed; for example, current approaches to improve service providers' skills do not emphasize communication and counselling, and consequently do not lead to improved client-provider interactions. The $\mathrm{MOH}$ also recognizes the critical importance of support systems such as MIS, commodity logistics, physical infrastructure and supervision to the improvement of service quality. The $\mathrm{MOH}$ has also been experimenting with innovative approaches to provider motivation for improving their performance (e.g. introducing a lunch allowance), and would like to identify and test other non-monetary motivational factors. 
Data from the 1995 UDHS and evaluations of the DISH Project suggest, however, that quality of care and client-provider interactions may not be major considerations for clients when choosing a clinic for family planning services. Clients appear to choose health facilities on the basis of proximity and knowledge of the services available. The $\mathrm{MOH}$ would like to know, therefore, whether improving quality of care does affect utilization of services.

The conceptual framework that guided the study design was drawn from all of these considerations. In this framework, it is hypothesised that a comprehensive intervention that tackles system, provider, and client related factors would lead to improved client-provider interactions, higher client satisfaction and to increasing family planning client load. It was also recognised, however, that most clinics in Uganda are currently not 'ready' to offer even basic levels of family planning services due to generalized shortages of different types of resources, and consequently the study was implemented in two phases. First, a package of interventions that address all three components was introduced in both experimental and comparison facilities to ensure that a basic level of readiness to offer family planning services was available. Second, the additive effect of focusing on provider motivation and satisfaction was addressed through introducing specific 'study' interventions in the experimental sites only.

\section{Study Methodology}

\section{Study objectives}

The general objective of the study was to assist the Uganda Ministry of Health to improve the quality of family planning services provided so that women and couples are better able to meet their fertility goals and be protected from STIs and HIV infections.

The specific objectives of the study were to assess the combined effects of the packages of interventions on:

- Clinic readiness to offer family planning services;

- Provider motivation;

- Provider competence;

- Quality of client-provider interactions; and

- Client load.

\section{Study design}

The study used a quasi-experimental design to compare a set of experimental clinics that received the full intervention package $\left(\mathrm{X}_{1-10}\right)$ with a set of comparison clinics that received only those interventions targeted at improving clinic readiness $\left(\mathrm{X}_{1-7}\right)$. This design allowed the study to compare the effect of the full and partial packages of interventions on the outcomes listed above. 
$\begin{array}{lccccc}\text { Months: } & \mathbf{1} & --------- & \mathbf{6 - 2 4} & --------- & \mathbf{3 0} \\ \text { Experimental sites } & 0_{1} & --------- & \mathrm{X}_{1-10} & ---------- & 0_{2} \\ \text { Comparison sites } & 0_{3} & --------- & \mathrm{X}_{1-7} & ---------- & 0_{4}\end{array}$

$\mathrm{X}_{1}$ : $\quad$ Updating policy guidelines and service standards

$\mathrm{X}_{2}$ : $\quad$ Ensuring availability of a minimum level of equipment and supplies required to provide pills, condoms, and injectables

$\mathrm{X}_{3}$ : $\quad$ Improving clinic environment

$\mathrm{X}_{4}$ : $\quad$ Increasing availability of appropriate IEC materials

$\mathrm{X}_{5}$ : $\quad$ Improving the health management information system

$\mathrm{X}_{6}$ : $\quad$ Building capacity for facilitative supervision

$\mathrm{X}_{7}$ : $\quad$ Improving provider competence

$\mathrm{X}_{8}$ : $\quad$ Building capacity for strategic planning and goal setting

$\mathrm{X}_{9}$ : $\quad$ Improving provider motivation

$\mathrm{X}_{10}$ : $\quad$ Raising clients' awareness of their rights to quality health care and their role in ensuring that quality care is provided to them

$0_{1} \& 0_{3} \quad$ Pre-intervention measurements of readiness to provide basic family planning services, provider competence, provider motivation, client-provider interactions, client satisfaction, and client load

$0_{2} \& 0_{4} \quad$ Post-intervention measurements of readiness to provide basic family planning services, provider competence, provider motivation, client-provider interactions, client satisfaction and client load.

The study was designed to test the following hypotheses:

- Clinics at which the complete set of ten interventions have been introduced will have better quality of client-provider interactions, more competent and better motivated providers, and will have higher client loads than those clinics at which the sub-set of seven 'readiness' interventions only have been introduced, and both groups of clinics will have better quality of client-provider interactions after the interventions than before;

- All clinics at which the interventions have been introduced will have higher family planning client loads after their introduction than before, and those clinics that have had all ten interventions will have larger increases than those having only the seven clinic 'readiness' interventions. 


\section{Data Collection}

The study sites consisted of Health Centres III \& IV in four districts (Kamuli, Luweero, Masaka, and Masindi) selected because they had similar socio-economic settings, health infrastructure, a moderate contraceptive prevalence rate, and a reasonably stable and accessible population. The districts were randomly selected from the subset of twelve districts covered by the DISH II Project. From the four matched districts, two districts, (Kamuli and Luweero) were randomly assigned to the experimental group, and the other two (Masaka and Masindi) were assigned to the comparison group.

In each district, 10 health centres of level III and IV were selected on the basis of accessibility (near enough to enable the research team to start at 8:00 a.m. each day), and FP client load, which needed to be large enough to meet the minimum sample size within the time available (see Table 1). The characteristics of Health Centres III and IV are described in Annex 1 .

Table 1: Distribution of facilities by type

\begin{tabular}{|c|c|c|}
\hline Level & $\begin{array}{c}\text { Experimental } \\
\mathrm{N}=20\end{array}$ & $\begin{array}{c}\text { Comparison } \\
\mathrm{N}=20\end{array}$ \\
\hline HC III & 11 & 14 \\
\hline HC IV & 9 & 6 \\
\hline
\end{tabular}

Data for the study were gathered through a combination of methods and instruments, and the sample sizes for each method are described in Table 2. A facility audit was completed in all 40 clinics before and after the intervention to document availability of infrastructure, basic family planning equipment, logistics and supplies, IEC materials and activities, record keeping and reporting.

The staff in charge of family planning services at each clinic and other family planning providers were interviewed using a structured questionnaire to measure their family planning knowledge, experiences, attitudes and practices. The same instrument was administered to providers before and after the intervention. It is not known whether the same staff were interviewed during the pre and post surveys as individual identifiers were not used. Because of regular staff turnover, it is likely that a small proportion of staff would have been different. Interactions between service providers and three categories of family planning clients were observed, both before and after the intervention. Originally, it was intended to observe a minimum of six new clients, six re-visit clients with problems and six re-visit clients for each
Table 2: Sample sizes by data collection method

\begin{tabular}{|l|c|c|c|c|}
\hline & \multicolumn{2}{|c|}{ Experimental } & \multicolumn{2}{c|}{ Comparison } \\
\hline & Pre & Post & Pre & Post \\
\hline Facility audit & 20 & 20 & 20 & 20 \\
\hline Provider interviews & 25 & 25 & 22 & 27 \\
\hline Client exit interviews & 375 & 332 & 249 & 315 \\
\hline Observed interactions & 375 & 332 & 249 & 315 \\
\hline
\end{tabular}


clinic, as this was felt to be the minimum number needed to ascertain the quality of clientprovider interactions. This proved not to be possible, especially in Masaka district where client load at the clinics was much lower than expected. The duration of each interaction was also documented.

Clients whose interactions with providers were observed were subsequently interviewed on exit to assess their satisfaction with, and opinion of, the services received. A total of 624 clients were observed and interviewed pre-intervention and 647 postintervention (see Table 3).

Table 3: Sample sizes by type of client

\begin{tabular}{|l|c|c|c|c|}
\hline Client category & \multicolumn{2}{|c|}{ Experimental } & \multicolumn{2}{c|}{ Comparison } \\
\hline & Pre & Post & Pre & Post \\
\hline New clients & 150 & 137 & 83 & 120 \\
\hline Continuing & & & & \\
clients & & & & \\
With problem & 110 & 89 & 74 & 63 \\
No problem & 115 & 106 & 92 & 132 \\
\hline Total & 375 & 332 & 249 & 315 \\
\hline
\end{tabular}

Activity sampling was used for the time motion study to determine how providers spent their time during a full working day. Observers followed one provider per day and used a stopwatch that beeped every three minutes. At the beep, the observer checked off the activity that was being performed using a form with a list of activities. The observer could also add activities to the list. Activities were coded into five categories: contacts with a client; carrying out administrative tasks; engaging in personal activities; not productive; and not at the clinic during work hours. Table 4 shows particular activities included in each of these categories.

Table 4: Category of provider activities

Data were also obtained on the number, duration and types of contacts. Each observer received a watch and used this to note start and end time for each consultation. The observer also noted the type of client, for example, family planning, antenatal care, curative, at postnatal.

Pre-intervention data were collected in November 2000 and post-intervention data in February 2002. Family planning interactions were to be observed for five days; during the pre-intervention survey, 212 observation days or just over 5 days per clinic were completed, while in the post-intervention, 235 days or about 6 days per clinic were completed. However, the number of days spent at each clinic

\begin{tabular}{|l|l|}
\hline \multicolumn{1}{|c|}{ Category } & \multicolumn{1}{c|}{ Activities } \\
\hline Contacts & Time with client \\
\hline Administrative & $\begin{array}{l}\text { Assisting another provider, organizing } \\
\text { work place, filling out client record, } \\
\text { material preparation, waiting for } \\
\text { cleaning of consultation room, getting } \\
\text { supplies, provide help to nurse } \\
\text { travelling to out reach activities, general } \\
\text { administrative tasks/paperwork, work } \\
\text { discussion with staff, work related } \\
\text { meeting, walking around work purpose, } \\
\text { work related telephone call, washing } \\
\text { hands, change of shift, work related } \\
\text { errand outside health facility/rounds, } \\
\text { and talking with consultant }\end{array}$ \\
\hline Personal & $\begin{array}{l}\text { Lunch/coffee break, in bathroom, and } \\
\text { gathering things at the end of day }\end{array}$ \\
\hline Not productive & $\begin{array}{l}\text { Waiting for client, personal matter } \\
\text { outside the clinic, non-work related } \\
\text { conversation, walking around (non-work } \\
\text { purpose), talking with observer, talking } \\
\text { with other clients/relatives, reading } \\
\text { newspaper, breastfeeding, personal } \\
\text { telephone call, and meeting with } \\
\text { personal visitors }\end{array}$ \\
\hline Not present when shift began, left shift \\
\hline
\end{tabular}


varied widely, from 2-14 days pre-intervention and 3-8 days post-intervention. These variations were due to client load, requiring the teams to spend more days at some clinics to try to meet the minimum sample size. Because equal numbers of clients were not included at each clinic, data were weighted to give equal weight to the clinics during the analysis.

\section{Project Interventions}

\section{Partner collaboration}

As a first step, the project sought collaboration with local partners - MOH, the DISH II Project and the district health services - to build on existing capacities and to facilitate sustainability. The DISH II Project had been supporting quality improvements in FP services for six years and had accumulated considerable experience. Clinics in the ten districts where DISH had operated had been upgraded and were at better levels of readiness than clinics elsewhere in the country. A partners' meeting was convened in June 2000 and consensus reached on the following modalities:

- DISH II Project, in collaboration with the MOH, would implement all interventions except those which sought to improve the clinic environment;

- The RCQHC was charged with overall management of the project, the research component, documenting the intervention process, and tracking the attendant costs;

- FRONTIERS monitored the project and provided technical support to the MOH and the RCQHC research team.

To forge a partnership with the study districts, the RCQHC Research Coordinator visited all study districts to discuss and agree on roles they could play during intervention implementation.

\section{Readiness interventions}

The readiness interventions were designed to enable all 40 clinics to offer a basic family planning service by bringing them to comparable functional levels. The seven interventions included:

1. Updating and disseminating the Reproductive Health $(\mathrm{RH})$ policy guidelines and service standards;

2. Ensuring the availability of minimum levels of equipment and supplies required to offer pills, injectables and condoms;

3. Improving the clinic environment;

4. Increasing the availability of appropriate family planning IEC materials;

5. Improving the Health Management Information System (HMIS); 
6. Building capacity of District and Sub-District Health Management Teams (S/DHMTs) to undertake facilitative supervision effectively; and

7. Improving provider competence in offering family planning services.

\section{Study interventions}

The study interventions were introduced through the Yellow Star Programme (YSP), a programme designed and implemented by the MOH and DISH II Project separately from this operations research study but also designed specifically to improve the quality of clientprovider interactions. These three interventions were introduced only in the 20 experimental clinics and included:

1. Building the capacity of Sub-District Health Management Teams (S/DHMT) for strategic planning and goal setting;

2. Improving provider motivation through non-monetary incentives; and

3. Increasing clients' awareness of and demand for good quality services.

\section{Implementing the interventions}

Implementation of the readiness and study interventions started in the early part of 2001 and lasted one year. An overview of each intervention is presented briefly below, and a summary of the intervention process is included in Annex II.

\section{Updating and dissemination of Reproductive Health (RH) policy guidelines and service standards}

The 1993 Reproductive Health (RH) policy guidelines were updated ${ }^{1}$, taking into account: 1) incorporating adolescent health, STI/HIV/AIDS, infertility, cancers, management of abortions, obstetric fistulae and gender based violence, in line with recommendations from the International Conference on Population and Development (ICPD) held in Cairo, 1994; and 2) the introduction of newer contraceptive methods in the country such as Norplant ${ }^{\circledR}$ implants and emergency contraception.

Ensuring the availability of minimum equipment and supplies required to offer Depo Provera, pills and condoms

The focus of this intervention was to ensure that basic equipment and supplies required to offer pills, condoms, and Depo Provera were available. In addition, the commodity logistics management system would be strengthened so that clinics could continue to receive basic equipment and supplies on a regular and timely basis from $\mathrm{MOH}$ stores.

The MOH constituted a working group comprising of staff of the Reproductive Health Division, representatives from Nurses and Midwives training schools, DISH II Project, the private midwives association, religious medical associations, development partners, and the Department of Obstetrics and Gynecology of Makerere University. The group reviewed the existing policy guidelines and standards for each component of $\mathrm{RH}$, identifying existing gaps and made recommendations. 


\section{Improving clinic environment}

Improving the clinic environment is intended to increase the privacy of client-provider interactions, and also enable clients waiting for services to feel more comfortable. It was envisaged to put in place minor improvements such as curtains or barriers to increase privacy, provide more chairs in the waiting area and provide drinking water for clients.

\section{Improving Health Management Information System (HMIS)}

The existing HMIS was updated to include the indicators for measuring the minimum RH care package disseminated to service providers. S/DHMT members' skills in data management and use of data for planning and decision-making were updated. The intervention also strengthened reporting and data management at the district level.

\section{Improving the availability of appropriate FP IEC materials}

Existing IEC materials were reviewed in terms of their availability in facilities and their appropriateness for family planning services. The logistics system would also be strengthened to ensure regular distribution of the materials to the study clinics.

\section{Building the capacity of district and sub-district supervisors for facilitative supervision}

Supervision was improved in health facilities through: 1) revising the National Supervision Guidelines (NSG) to give prominence to family planning services; 2) disseminating the guidelines to district and HSD managers and service providers; and 3) monitoring the utilization of the guidelines during routine supportive supervision of RH services.

\section{Improving provider competence}

The process and content of family planning client-provider interactions was improved through addressing two components: the technical competence of providers and their motivation. District and Health sub-district managers organized formal refresher-training workshops in RH/FP for qualified staff drawn from the study facilities. A pre-requisite for selection was having undergone a six week integrated reproductive health basic training during DISH I. The three-day refresher training was intended to update provider knowledge and skills in RH, using the revised RH guidelines and service standards. Topics in the family planning module included: Introduction to FP services; FP methods available; Counseling; Screening for FP methods; Providing FP methods; Managing side effects and complications of FP methods; STI/HIV/AIDS; and HMIS.

During quarterly visits for support supervision and assessment of basic standards, supervisors made observations of three client-provider interactions in each facility to assess both technical competence and interpersonal relationships exhibited by providers. Supervision provided opportunities for corrective measures to improve and sustain high quality interactions.

Building capacity of DHMTs and S/DHMTs for strategic planning and goal setting, improving provider motivation, and increasing clients awareness of and demand for quality services

A package of study interventions was designed and implemented to improve provider motivation and quality of client-provider interactions. The package was introduced in the 
experimental clinics only and after the readiness interventions had been implemented. The three interventions of this package were implemented under the Yellow Star Programme (YSP). This programme is fully described in Annex III.

The YSP is the MOH's strategy to improve and sustain quality of care through supervision, recognition and reward of facilities/staff who attain and maintain basic standards for quality of services. The YSP builds upon the existing foundation of health care services and was integrated into the current supervision system in order to be consistent with the policies and procedures already in place. Introduction of the YSP evolved through three stages:

establishing basic standards for quality; communicating the standards to the stakeholders; and monitoring and certification of facilities attaining and maintaining standards.

\section{Study Results}

\section{Overview of analysis plan}

The study was designed to achieve two outcomes:

1. Bring both groups of clinics to equivalent levels of 'readiness' to offer FP services by implementing seven readiness interventions; and

2. Implement three 'study' interventions in the experimental clinics only, which would improve the quality of client-provider interactions (CPI) and increase client load.

The analysis sought to show:

- The level of readiness that has been achieved in both groups of clinics by comparing pre- and post-intervention measures for both groups.

- Whether any significant difference in readiness occurred between the two groups, which can be shown by comparing the post-intervention readiness measures for each group.

- Whether the study interventions improved planning capacity, provider motivation and client awareness, which can be shown by comparing study intervention indicators pre- and post-intervention within the experimental group, and by comparing the experimental and comparison groups post-intervention.

- Whether adding the study interventions to the experimental groups improved the CPI and the client load compared with the comparison group, which can be shown by comparing these measures post-intervention for the two groups.

\section{Readiness to offer quality family planning services}

The underlying principle that guided the clinic readiness interventions was to ensure that all 40 clinics in the experimental and comparison sites attained relatively comparable levels of capacity to offer quality FP services. It was further assumed that once this level of readiness was put in place it would be sustained in all sites. 
Five indicators were used to measure readiness within the clinic, i.e. availability of revised RH policy guidelines and standards; availability of minimum FP equipment; availability of FP commodities; satisfactory clinic environment; availability of appropriate FP IEC materials (especially charts, brochures and posters). A sixth clinic-level component, a functioning HMIS, was also developed comprising nine sub-indicators. Three indicators measured readiness at the provider level: appropriate supervision; satisfactory provider competence; and efficient provider time use.

\section{Clinic readiness}

An index of clinic readiness was constructed using the five indicators as follows:

- Availability of minimum equipment to offer FP services (score 0 - 3). The $\mathrm{MOH}$ recommends that for a clinic to offer basic FP services it needs to have, at a minimum, a blood pressure machine, a weighing scale for adults, and a stethoscope.

- Availability of FP contraceptive supplies (score 0-5). Clinics are expected to offer five methods: combined pills, progestin only pills, condoms, Depo Provera, and Norplant ${ }^{\circledR}$ implants.

- Availability of FP IEC materials (score 0-3). All clinics are expected to have charts, brochures and posters.

- Availability of RH guidelines (score $0-1$ ). Are the RH policy guidelines and service standards available? These were introduced as part of the readiness intervention and so were only measured post-intervention.

- Satisfactory clinic environment (score 0-4). Clinics were assessed in terms of their visual privacy, auditory privacy, client seating and availability of examination couches.

Data were drawn from clinic inventories and mean scores computed for each indicator, and then aggregated across all indicators to give the composite score for clinic readiness. The analysis of variance (ANOVA) statistical test was used to detect significance of differences between the experimental and comparison clinics in the pre-test and post-test measures.

The findings (Table 5) indicate slight improvements in scores for contraceptive supplies and clinic environment in both groups of clinics to comparable levels. Availability of IEC materials improved slightly in the experimental clinics only, and the availability of FP equipment showed very little change.

Table 5: Clinic readiness

\begin{tabular}{|l|c|c|c|c|}
\hline & \multicolumn{2}{|c|}{ Experimental } & \multicolumn{2}{c|}{ Comparison } \\
\hline & $\begin{array}{c}\text { Pre } \\
\mathrm{N}=20\end{array}$ & $\begin{array}{c}\text { Post } \\
\mathrm{N}=20\end{array}$ & $\begin{array}{c}\text { Pre } \\
\mathrm{N}=20\end{array}$ & $\begin{array}{c}\text { Post } \\
\mathrm{N}=20\end{array}$ \\
\hline $\begin{array}{l}\text { Revised RH guidelines } \\
\text { (Score: } 0 \text { - 1) }\end{array}$ & $\mathrm{NA}$ & 0.2 & $\mathrm{NA}$ & 0.6 \\
\hline $\begin{array}{l}\text { Minimum FP equipment } \\
\text { (Score: } 0 \text { - 3) }\end{array}$ & 2.5 & 2.4 & 2.2 & 2.4 \\
\hline $\begin{array}{l}\text { Contraceptive supplies } \\
\text { (Score: } 0 \text { - 5) }\end{array}$ & 3.7 & 4.4 & 3.7 & 4.4 \\
\hline $\begin{array}{l}\text { Clinic environment } \\
\text { (Score: } 0-4)\end{array}$ & 3.0 & 3.3 & 3.0 & 3.6 \\
\hline $\begin{array}{l}\text { FP IEC materials } \\
\text { (Score: 0- 3) }\end{array}$ & 2.5 & 2.7 & 2.4 & 2.4 \\
\hline Mean Score (0-1) & $\mathbf{0 . 7 8}$ & $\mathbf{0 . 8 1}$ & $\mathbf{0 . 7 5}$ & $\mathbf{0 . 8 4}$ \\
\hline
\end{tabular}


Availability of the revised RH guidelines was particularly low in the experimental clinics. This may be because some clinic staff prefer to keep guidelines at their residence, thus restricting access to other providers, or there was insufficient distribution of the guidelines to the health facilities.

However, it is important to note that although both experimental and comparison groups registered slight overall improvements in clinic readiness, there was no statistically significant difference between the scores for the pre- and post-intervention measures, or between the experimental and comparison groups. This suggests that both groups of clinics were already at comparable levels of readiness, and that readiness did not change after introduction of the interventions. This may well be because, as can be seen from the readiness scores for the pre-intervention survey, on averages the clinics already had quite high levels of readiness for offering basic family planning services.

\section{Functioning HMIS}

The indicators used to measure a functional HMIS included supplies of record books, availability of staff trained in record keeping and data management, routine reporting, analysis and utilization of locally generated data on site.

The results (Table 6) indicate that, with the exception of referral slips and the HMIS database, basic supplies for a functioning HMIS were generally available in both groups of clinics. Most comparison clinics did not have the HMIS database manual for 2002 on site because of delays in distribution of the revised HMIS. These clinics improvised by filing individual HMIS forms in one folder. Almost all clinics had copies of HMIS returns for the previous three months, an indication that they were Table 6: Percent of HMIS supplies and reports available reporting to higher-level facilities. The completeness, timeliness and accuracy of these reports were not assessed. Despite these encouraging findings, data from the provider interviews show that only 36 percent of the providers in comparison clinics were oriented on the revised HMIS, an indication of the very limited reach of this intervention in the

\begin{tabular}{|l|c|c|c|c|}
\hline & \multicolumn{2}{|c|}{ Experimental } & \multicolumn{2}{c|}{ Comparison } \\
\hline & $\begin{array}{c}\text { Pre } \\
\mathrm{N}=20\end{array}$ & $\begin{array}{c}\text { Post } \\
\mathrm{N}=20\end{array}$ & $\begin{array}{c}\text { Pre } \\
\mathrm{N}=20\end{array}$ & $\begin{array}{c}\text { Post } \\
\mathrm{N}=20\end{array}$ \\
\hline FP cards & 90 & 70 & 85 & 90 \\
\hline Record books & 100 & 90 & 95 & 100 \\
\hline HMIS 105 forms & 100 & 100 & 95 & 95 \\
\hline Referral slips & 30 & 30 & 60 & 60 \\
\hline HMIS database 2002 manual & NA & $65^{\star * *}$ & NA & $5^{\star * *}$ \\
\hline Stock cards & NA & 90 & NA & 95 \\
\hline HMIS returns for prior 3 months & NA & 100 & NA & 100 \\
\hline
\end{tabular}

Source: Facility inventory \& provider interview *** $P<0.001$

NA: Not assessed pre-intervention comparison districts.

\section{Supervision}

Supervision was assessed in terms of availability of the National Supervision Guidelines (NSG), orientation of supervisors about the National Supervision Guidelines, whether clinics received supportive supervision (SS), and providers' perceived benefits from supportive supervision. Although all units were expected to have received the NSG, Table 7 reveals that 
several clinics lacked the document on site. The two groups were compared both pre- and post-intervention. The study findings (Table 7) show that both groups differed only marginally in terms of orientation of supervisors on the NSG. All clinics from the experimental group that had the NSG had a trainer who received an orientation on how to use the guidelines compared to only 68 percent of those in the comparison group.
Table 7: Clinic readiness and supportive supervision

\begin{tabular}{|l|c|c|c|c|}
\hline \multirow{2}{*}{} & \multicolumn{2}{|c|}{ Experimental } & \multicolumn{2}{c|}{ Comparison } \\
\cline { 2 - 5 } & Pre & Post & Pre & Post \\
\hline $\begin{array}{l}\text { Availability of revised } \\
\text { supervision guidelines }\end{array}$ & $\mathrm{NA}$ & $\begin{array}{c}65 \% \\
(\mathrm{~N}=20)\end{array}$ & $\mathrm{NA}$ & $\begin{array}{c}75 \% \\
(\mathrm{~N}=20)\end{array}$ \\
\hline $\begin{array}{l}\text { Provider oriented to use } \\
\text { supervision guidelines }\end{array}$ & $\mathrm{NA}$ & $\begin{array}{c}100 \% * \\
(\mathrm{~N}=13)\end{array}$ & $\mathrm{NA}$ & $\begin{array}{c}68 \%^{*} \\
(\mathrm{~N}=15)\end{array}$ \\
\hline $\begin{array}{l}\text { Clinic supervised at least once } \\
\text { in 6 months }\end{array}$ & $\begin{array}{c}90 \% \\
(\mathrm{~N}=20 \\
)\end{array}$ & $\begin{array}{c}95 \% \\
(\mathrm{~N}=20)\end{array}$ & $\begin{array}{c}95 \%) \\
(\mathrm{N}=20 \\
)\end{array}$ & $\begin{array}{c}100 \% \\
(\mathrm{~N}=20)\end{array}$ \\
\hline $\begin{array}{l}\text { Supervisors recognized } \\
\text { supervisees }\end{array}$ & $\begin{array}{c}48 \% \\
(\mathrm{~N}=25 \\
)\end{array}$ & $\begin{array}{c}71 \% * * \\
* \\
(\mathrm{~N}=25)\end{array}$ & $\begin{array}{c}41 \% \\
(\mathrm{~N}=22 \\
)\end{array}$ & $\begin{array}{c}19 \% * * \\
* \\
(\mathrm{~N}=27)\end{array}$ \\
\hline $\begin{array}{l}\text { Supervision improved work } \\
\text { performance }\end{array}$ & $\mathrm{NA}$ & $\begin{array}{c}92 \% \\
(\mathrm{~N}=25)\end{array}$ & $\mathrm{NA}$ & $\begin{array}{c}96 \% \\
(\mathrm{~N}=27)\end{array}$ \\
\hline
\end{tabular}

Source: Facility audit and provider interviews

${ }^{*} P<0.05 \quad{ }^{* * *} P=0.001$

NA: Not assessed pre-intervention

Virtually all clinics were

supervised in the last six months. Significantly more providers in the experimental than comparison clinics reported that their supervisors gave them due recognition during supervisory visits in terms of praising their performance and rewarding them by inviting them to attend training workshops or giving them tee-shirts and other small tokens. This could be attributed to the YSP (implemented in the experimental sites only), which placed strong emphasis on supportive supervision.

\section{Provider Competence}

Provider competence was assessed on the basis of provider knowledge of important information about commonly offered contraceptive methods, how much of the essential information was obtained from new FP clients during consultations, and provider compliance with infection control guidelines during injection administration.

\section{Provider knowledge}

Providers were asked what information they would give to new family planning clients who had chosen a method regarding its effectiveness, contraindications, side effects, use instructions, and alarm signs. A spontaneously correct response scored 2 marks, a prompted correct response scored 1 mark, and an incorrect or non-response scored 0 . The mean scores for seven contraceptive methods that are normally discussed during counselling were computed to generate knowledge indices for the individual methods and an overall composite knowledge index for all methods. Only providers who had participated in a Reproductive Health Refresher Training/Update were included in the analysis. The experimental and comparison group were compared both pre- and post-intervention. 
The knowledge level among providers in both experimental and comparison groups was very low for all methods (Table 8), even after introduction of the interventions. The knowledge index did improve significantly in the experimental clinics after the interventions, but it also declined significantly in the comparison clinics, with no significant difference between the two groups postintervention. These findings suggest that not only do most
Table 8: Provider knowledge scores of different contraceptive methods

\begin{tabular}{|l|c|c|c|c|}
\hline \multirow{2}{*}{ Method } & \multicolumn{2}{|c|}{ Experimental } & \multicolumn{2}{c|}{ Comparison } \\
\cline { 2 - 5 } & $\begin{array}{c}\text { Pre } \\
\mathrm{N} \\
=20\end{array}$ & $\begin{array}{c}\text { Post } \\
\mathrm{N}=1 \\
3\end{array}$ & $\begin{array}{c}\text { Pre } \\
\mathrm{N}=1 \\
4\end{array}$ & $\begin{array}{c}\text { Post } \\
\mathrm{N} \\
=20\end{array}$ \\
\hline Mini pill (Score: 0 - 46) & 17 & 21 & 13 & 14 \\
\hline $\begin{array}{l}\text { Combined pill (Score: 0 - } \\
\text { 64) }\end{array}$ & 26 & $29^{* *}$ & 29 & $22^{* *}$ \\
\hline Injectable (Score: 0 - 48) & 16 & 16 & 16 & 13 \\
\hline Condom (Score: 0 - 30) & 14 & $18^{*}$ & 14 & $13^{*}$ \\
\hline Rhythm (Score: 0 - 18) & 5 & 6 & 4 & 3 \\
\hline IUD (Score: 0 - 46) & 16 & 16 & 13 & 12 \\
\hline Tubal ligation (Score: 0 - 20) & 11 & 15 & 10 & 12 \\
\hline All methods (Score: 0 - 272) & 105 & $121^{*}$ & 99 & $89^{*}$ \\
\hline
\end{tabular}

Source: Provider Interviews ${ }^{*} \mathrm{P}<0.05{ }^{* *} \mathrm{P}<0.01$

providers in Health Centres III and IV have poor knowledge about contraceptives, but also the type of in-service training provided through this project was not adequate or appropriate for increasing this to a much higher level. The fact that knowledge did increase in the experimental sites suggests that some aspect of the YSP may have contributed to improving provider knowledge.

\section{Information obtained from clients}

The information that should be elicited from new clients includes the client's social context (for example, partner's attitude to contraception, exposure to domestic violence), breastfeeding status, past contraceptive experiences, and fertility intentions. The observations of client-provider interactions (see Table 9) indicate that providers registered significantly higher overall scores for eliciting information from clients in the experimental clinics after the interventions, with slight improvements in all categories
Table 9: Mean score of essential information elicited from new clients

\begin{tabular}{|l|c|c|c|c|}
\hline \multirow{2}{*}{} & \multicolumn{2}{|c|}{ Experimental } & \multicolumn{2}{c|}{ Comparison } \\
\cline { 2 - 5 } & $\begin{array}{c}\text { Pre } \\
\mathrm{N} \\
=150\end{array}$ & $\begin{array}{c}\text { Post } \\
\mathrm{N}=13 \\
7\end{array}$ & $\begin{array}{c}\text { Pre } \\
\mathrm{N}=8 \\
3\end{array}$ & $\begin{array}{c}\text { Post } \\
\mathrm{N} \\
=120\end{array}$ \\
\hline $\begin{array}{l}\text { Fertility intentions } \\
\text { (Score 0-2) }\end{array}$ & 0.93 & 1.07 & 0.66 & 0.83 \\
\hline $\begin{array}{l}\text { Social context } \\
\text { (Score: 0-4) }\end{array}$ & 1.00 & 1.05 & 1.22 & 0.80 \\
\hline $\begin{array}{l}\text { Contraceptive } \\
\text { experience } \\
\text { (Score 0-1) }\end{array}$ & 0.64 & 0.72 & 0.59 & 0.71 \\
\hline $\begin{array}{l}\text { Concerns about method } \\
\text { (Score 0-2) }\end{array}$ & 0.64 & 0.93 & 0.84 & 0.53 \\
\hline $\begin{array}{l}\text { Medical history } \\
\text { (Score 0-1) }\end{array}$ & 0.42 & 0.60 & 0.55 & 0.65 \\
\hline $\begin{array}{l}\text { Breastfeeding status } \\
\text { (Score0-1) }\end{array}$ & 0.43 & 0.53 & 0.61 & 0.57 \\
\hline $\begin{array}{l}\text { Total score } \\
\text { (Score: 0 - 11) }\end{array}$ & $\mathbf{4 . 0 7}$ & $\mathbf{4 . 9 0 ^ { * }}$ & $\mathbf{4 . 4 8}$ & $\mathbf{4 . 0 8 *}$
\end{tabular}


of information being gathered.

However, provider performance in the comparison sites was significantly poorer after the introduction of the interventions, although there had been some slight improvements in selected items of information. This may be due to interviewing different providers in the pre and post surveys, but as individual identifiers were not used it is not possible to know. As with the indicators of provider knowledge, there appears to be some effect on performance due to the YSP being introduced in the experimental areas. However, the concern remains that there may be decreases in providers' ability to elicit key information from their family planning clients after the readiness interventions have been introduced, and so it is essential that the content and nature of the training used is critically appraised.

\section{Compliance with infection control guidelines}

Given the popularity of the

injectable method, the study

also assessed whether

providers complied with

stipulated infection control

guidelines during clinical

procedures when

administering this method.

As Table 10 indicates,

providers maintained, and in

many instances improved,

compliance with standard

procedures for infection

control. However, a

Table 10: Percentage of injectable client interactions in which the provider complied with selected infection control procedures

\begin{tabular}{|l|c|c|c|c|}
\hline \multirow{2}{*}{ Infection control procedures } & \multicolumn{2}{|c|}{ Experimental } & \multicolumn{2}{c|}{ Comparison } \\
\cline { 2 - 5 } & $\begin{array}{c}\text { Pre } \\
\mathrm{N}=166\end{array}$ & $\begin{array}{c}\text { Post } \\
\mathrm{N}=146\end{array}$ & $\begin{array}{c}\text { Pre } \\
\mathrm{N}=155\end{array}$ & $\begin{array}{c}\text { Post } \\
\mathrm{N}=210\end{array}$ \\
\hline Washed hands & 9 & $51^{* \star *}$ & 30 & $24^{* \star *}$ \\
\hline Cleaned injection site & 42 & 69 & 87 & 72 \\
\hline Use sterile needle \& syringe & 99 & 99 & 97 & 99 \\
\hline Disposed sharps safely & 68 & $85^{*}$ & 65 & $75^{*}$ \\
\hline
\end{tabular}

Source: Observation of injection practices during administration of Depo Provera

${ }^{*} \mathrm{P}<0.05{ }^{* * *} \mathrm{P}<0.001$

comparison of experimental

and comparison group post- intervention shows greatest improvement in the experimental sites, where hand washing before and after administering injections and disposal of sharps improved significantly. This may be because the study interventions (i.e. the YSP) also emphasized these activities. The use of sterile needles and syringes remained universal. Although the facility audits had indicated a shortage of sterile syringes in many facilities, clients were asked to purchase and bring their own syringes, which it appears they did.

\section{Provider time use}

It is frequently asserted that improvements in quality of care could lead to increases in the duration of interactions between providers and clients. Data were therefore collected on how providers spent their time using a time motion study, through which a provider was observed continuously to determine her activities in the clinic from 8:00 a.m. to 5:00 p.m. (official $\mathrm{MOH}$ working hours). Table 11 provides information on the average length of interactions by type of service. The average contact length was considerably longer in the experimental than in the comparison group. Even when controlling for type of interaction, those in the experimental group were generally longer in both the pre- and post-intervention observations. 
For example, the average length of a family planning interaction was 5 to 8 minutes longer in the experimental group. In both groups, the average length of a visit increased by about one minute from pre-intervention to post-intervention although the changes are not consistent across the different contact categories.

Table 11: Average length for interactions

\begin{tabular}{|l|c|c|c|c|c|c|c|c|}
\hline & \multicolumn{4}{|c|}{ Experimental } & \multicolumn{4}{c|}{ Comparison } \\
\hline & $\begin{array}{c}\text { Pre } \\
\text { (minutes } \\
\text { ) }\end{array}$ & $\mathrm{N}$ & $\begin{array}{c}\text { Post } \\
\text { (minutes } \\
\text { ) }\end{array}$ & $\mathrm{N}$ & $\begin{array}{c}\text { Pre } \\
\text { (minutes } \\
\text { (minty }\end{array}$ & $\mathrm{N}$ & $\begin{array}{c}\text { Post } \\
\text { (minutes) }\end{array}$ & $\mathrm{N}$ \\
\hline $\begin{array}{l}\text { Family } \\
\text { Planning }\end{array}$ & 24 & 203 & 28 & 178 & 19 & 123 & 19 & 201 \\
\hline Antenatal & 12 & 446 & 15 & 627 & 12 & 431 & 11 & 657 \\
\hline $\begin{array}{l}\text { Immunization } \\
\text { / well baby } \\
\text { care }\end{array}$ & 12 & 57 & 8 & 139 & 4 & 102 & 9 & 171
\end{tabular}

Table 12: Average number of interactions by type of service per observation day

\begin{tabular}{|l|c|c|c|c|}
\hline \multirow{2}{*}{\multicolumn{1}{|c|}{ Type of contact }} & \multicolumn{2}{c|}{ Experimental } & \multicolumn{2}{c|}{ Comparison } \\
\cline { 2 - 5 } & Pre & Post & Pre & Post \\
\hline Family planning & 2.05 & 1.48 & 1.09 & 1.75 \\
\hline Antenatal care & 4.51 & 5.23 & 3.81 & 5.71 \\
\hline $\begin{array}{l}\text { Immunization/well baby } \\
\text { care }\end{array}$ & 0.58 & 1.16 & 0.90 & 1.49 \\
\hline Curative & 1.82 & 1.18 & 5.17 & 4.26 \\
\hline Total & 9.84 & 10.20 & 11.28 & 13.63 \\
\hline Observation days & 99 & 120 & 113 & 115 \\
\hline
\end{tabular}

${ }^{*}$ Total includes postnatal, group talk, labour/delivery, and unknown contacts in which total of each was less than 20

\begin{tabular}{|l|c|c|c|c|c|c|c|c|}
\hline Curative care & 11 & 180 & 15 & 142 & 7 & 584 & 7 & 490 \\
\hline Total $^{*}$ & 16 & 974 & 17 & 1224 & 10 & 1275 & 11 & 1567 \\
\hline
\end{tabular}

Table 12 shows the average number of contacts by type of service per provider per day. The average number of daily interactions was higher in the comparison than in the experimental group, and the number of interactions increased after the interventions in both groups. Providers were seeing, on average, about 3 clients more in the comparison than in the experimental group.

There were some important differences between the two groups in the types of clients seen, however. In the experimental group, about half of the clients came for antenatal care, and this proportion did not change over time. In the comparison group, however, visits for curative care dominated in the pre-intervention, but antenatal care visits dominated in the post-intervention period. It should be noted that the number of family planning interactions 
remained between one and two per day, this number decreased slightly in the experimental group.

Figure 1 describes how providers allocate their contact time with clients across visits of different types. The percentage of time spent with clients for a particular type of contact may be high if the number of contacts is high or their average length is long. Thus, while the number of family planning contacts is low, they occupy a higher percentage of time because these contacts are, on average, the longest. In contrast, the time taken up by curative care contacts in the comparison group is lower than one would expect based on the high number of contacts of this type, but these contacts are very short.

\section{Figure 1: Distribution of time spent with each type of client by group}

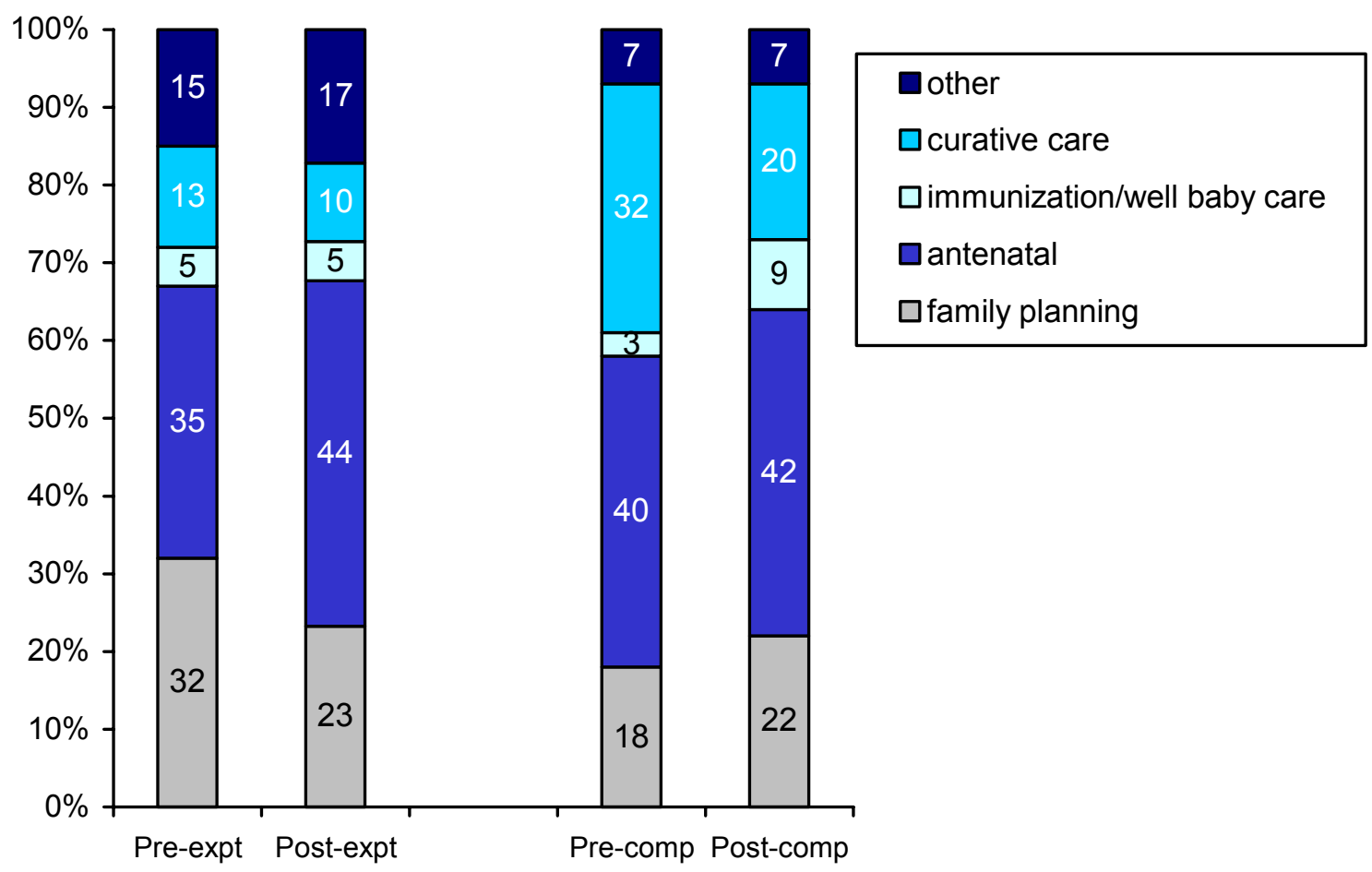

In the experimental group, the highest percentage of time is spent with antenatal care and family planning clients, although after the interventions less time was spent with family planning clients. Given that visits are, on average, one minute longer after the intervention and, in the case of the comparison group, providers see more clients, the percentage of time that providers spend with clients should increase, and this change should be greater in the comparison than in the experimental group.

Figure 2 shows how providers distributed their time across various categories of activities during the average day spent at the clinic. The percentage of time spent with clients increased after the interventions, although the change was small. About one quarter to one third of the 9 hours that providers are expected to be at the clinic is spent with clients.

Administrative work accounts for about 18-19 percent of time. About 40 percent or more of a provider's day is spent either not being productive or simply not being there. After the 
interventions, there was a decrease, which was larger in the comparison group, in the percentage of time that providers spent unproductively at the clinic, but no change in the percentage of time not being at the work place.

\section{Figure 2: $\quad$ Percentage distribution of how providers spend their day}

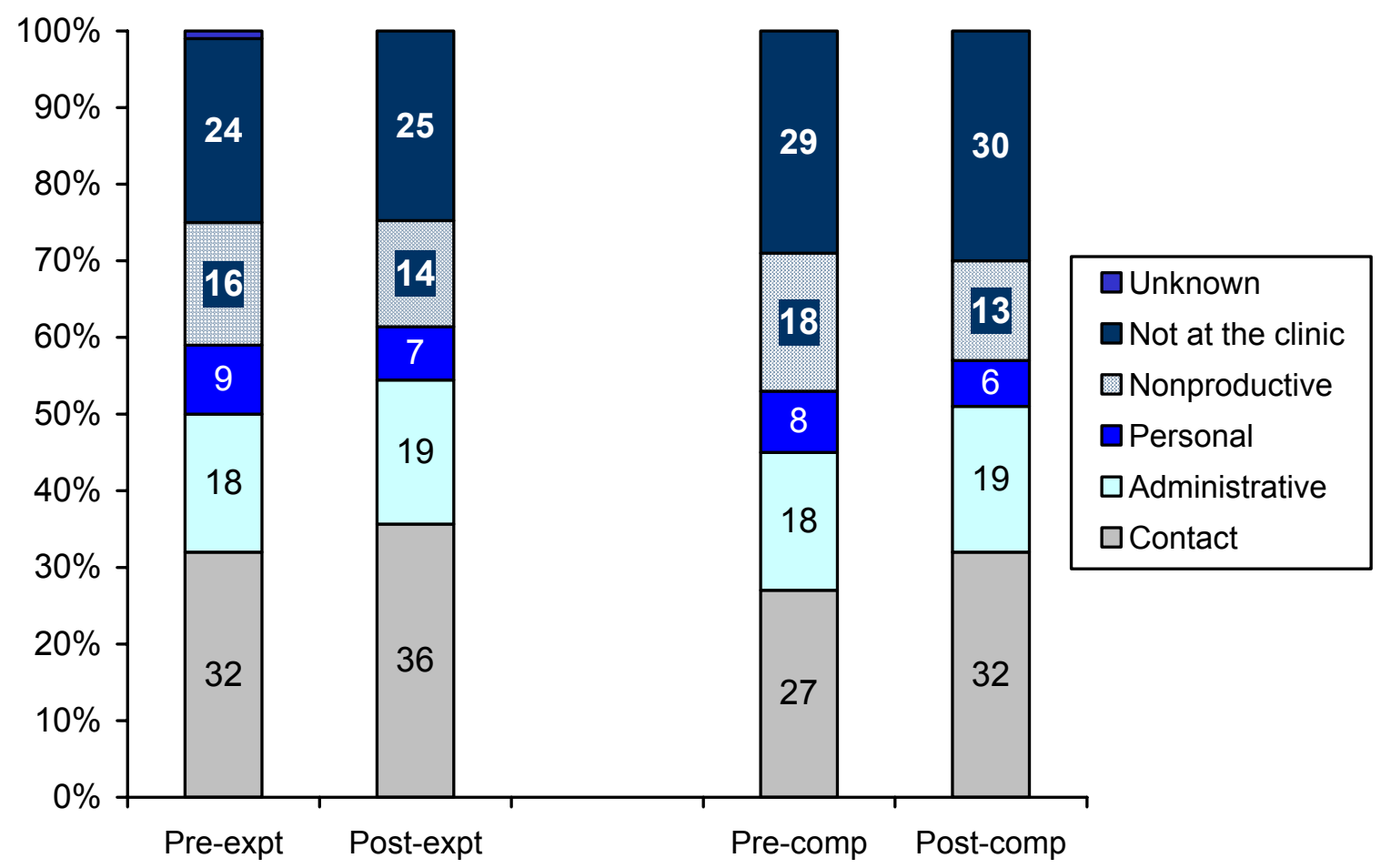

These results suggest that providers responded to an increase in demand for services by spending more time with clients during the hours that they were at the clinic, but did not spend more work hours at the clinic. While some contacts increased in duration, on average, the amount of time spent with a client changed little. Thus, additional time was not needed by providers to see more clients.

The combination of small increases in the average length of contacts in both groups, and in the average number of contacts in the comparison group, is associated with an increase in the percentage of time that providers spend with clients. The reason for this increase in provider time spent with clients would appear to be unrelated to the intervention as the increase is greater in the comparison than in the intervention group.

The additional time spent with clients was apparently drawn from unproductive time. However, if there were to be larger increases in the demand for clinic services, providers would have to find other ways of meeting that demand, probably by spending more time at the clinics during official hours. 


\section{Output of study interventions}

\section{Provider motivation}

One key component of the study interventions, i.e. the YSP, was the introduction of recognition and a non-monetary reward system to facilities and providers that achieve and maintain basic standards of care. It was assumed that, together with better clinic readiness, this intervention would be translated into better-motivated providers and consequently improved quality of family planning services. Ten indicators of job satisfaction (Table 13) were used to measure motivation. Mean scores were computed for each indicator, and an overall composite index calculated for satisfaction. Experimental and comparison groups were compared both preand post-intervention. As shown in Table 13, provider satisfaction improved in all sites, and providers in the experimental sites showed significantly higher satisfaction after the interventions than providers in the comparison sites. Unexpectedly, a significant decline in satisfaction with FP commodities and supplies was found in the comparison sites, despite there having been a slight improvement in the actual availability of these commodities and supplies in comparison clinics. This inconsistent finding

Table 13: Mean scores of provider job satisfaction

\begin{tabular}{|c|c|c|c|c|}
\hline \multirow[b]{2}{*}{ Provider satisfaction with ... } & \multicolumn{2}{|c|}{ Experimental } & \multicolumn{2}{|c|}{ Comparison } \\
\hline & $\begin{array}{l}\text { Pre } \\
\mathrm{N}=22\end{array}$ & $\begin{array}{l}\text { Post } \\
\mathrm{N}=25\end{array}$ & $\begin{array}{l}\text { Pre } \\
\mathrm{N}=25\end{array}$ & $\begin{array}{l}\text { Post } \\
\mathrm{N}=27\end{array}$ \\
\hline Providing FP services & 0.88 & 1.00 & 0.59 & 0.82 \\
\hline $\begin{array}{l}\text { Performances as FP } \\
\text { providers }\end{array}$ & 0.84 & 0.88 & 0.59 & 0.89 \\
\hline $\begin{array}{l}\text { Work conditions in their } \\
\text { facility }\end{array}$ & 0.64 & 0.80 & 0.50 & 0.52 \\
\hline Relationship with FP clients & 0.96 & 1.00 & 1.00 & 0.93 \\
\hline FP equipment & 0.40 & 0.84 & 0.41 & 0.41 \\
\hline $\begin{array}{l}\text { FP commodities and } \\
\text { supplies }\end{array}$ & 0.44 & 0.76 & $0.73^{*}$ & $0.48^{*}$ \\
\hline $\begin{array}{l}\text { Support from their } \\
\text { supervisors }\end{array}$ & 0.88 & 0.96 & 0.59 & 0.74 \\
\hline Amount of FP work they do & 0.68 & 0.72 & 0.55 & 0.74 \\
\hline $\begin{array}{l}\text { Opportunities for learning \& } \\
\text { developing in their jobs }\end{array}$ & 0.48 & 0.64 & 0.41 & 0.44 \\
\hline $\begin{array}{l}\text { What is expected of them } \\
\text { as FP providers }\end{array}$ & $0.76^{*}$ & $0.92^{*}$ & $0.46^{*}$ & $0.78^{*}$ \\
\hline Total score (Range: $0-10)$ & 7.0 & $8.5^{* * *}$ & 5.8 & $6.7^{* * *}$ \\
\hline
\end{tabular}

highlights the subjectivity of measuring provider satisfaction.

\section{Client empowerment}

Client empowerment was measured using two indicators: whether new clients were observed asking questions during counselling sessions, and whether they reportedly did not feel too shy to ask questions. The results (Table 14) show that many new clients who attended experimental clinics
Table 14: Percentage of clients who did not feel shy and asked questions

\begin{tabular}{|l|c|c|c|c|}
\hline \multirow{2}{*}{} & \multicolumn{2}{|c|}{ Experimental } & \multicolumn{2}{c|}{ Control } \\
\cline { 2 - 5 } & Pre & Post & Pre & Post \\
& $\mathrm{N}=15$ & $\mathrm{~N}=13$ & $\mathrm{~N}=8$ & $\mathrm{~N}=12$ \\
0 & 7 & 3 & 0 \\
\hline Client asked questions & 83 & 88 & 66 & 76 \\
\hline Client did not feel too & 84 & 91 & 83 & 90
\end{tabular}


were already asking questions uninhibited before the interventions, and this situation did not significantly improve. In the comparison clinics, somewhat fewer clients were observed asking questions during counselling sessions, but this improved slightly after the interventions, although not significantly.

\section{Effect of study interventions on CPI and client load}

\section{Client-provider interaction (CPI)}

The quality of CPI was measured using a scale derived from two major components of quality: interpersonal relations and information exchange (see Bruce 1990). The scale measures quality before and after the interventions, and has been used by the other global agenda studies to facilitate comparisons in different situations. The scale was formed by aggregating the scores of nine indicators, comprising 22 individual items. The items were generated from the client exit interviews or observation of new client provider interactions, and each item was scored 1 (yes) or 0 (no). The analysis was restricted to new family planning clients since they were expected to receive a full range of information to enable them to select and use the new methods effectively. The mean score was computed for each indicator and for each study group. MannWhitney U test statistics were used to test for significance of difference of the composite indicators for the experimental and comparison districts, both in the baseline and postintervention.

A comparison of preand post- intervention scores (Table 15) shows a significant improvement in CPI over time in both experimental and comparison groups.

This suggests that the readiness interventions contributed to improving the quality of client provider

Table 15: The Quality of Client Provider Interactions

\begin{tabular}{|l|c|c|c|c|c|c|}
\hline & \multicolumn{3}{|c|}{ Experimental } & \multicolumn{3}{c|}{ Comparison } \\
\hline Indicators & $\begin{array}{c}\text { Pre } \\
\mathrm{N}=15 \\
0\end{array}$ & $\begin{array}{c}\text { Post } \\
\mathrm{N}=13 \\
7\end{array}$ & $\mathrm{p}$ & $\begin{array}{c}\text { Pre } \\
\mathrm{N}=83\end{array}$ & $\begin{array}{c}\text { Post } \\
\mathrm{N}=12 \\
0\end{array}$ & $\mathrm{p}$ \\
\hline $\begin{array}{l}\text { Interpersonal } \\
\text { relations } \\
\text { (Score: } 0-3)\end{array}$ & 2.92 & 2.85 & 0.074 & 2.77 & 2.90 & 0.060 \\
\hline $\begin{array}{l}\text { Need diagnosis } \\
\text { (Score: } 0-3)\end{array}$ & 2.15 & 2.31 & 0.073 & 1.84 & 2.03 & 0.204 \\
\hline $\begin{array}{l}\text { Method choice } \\
\text { (Score: } 0-3)\end{array}$ & 2.01 & 2.32 & 0.001 & 2.31 & 2.25 & 0.382 \\
\hline $\begin{array}{l}\text { Contraindication } \\
\text { (Score: } 0-2)\end{array}$ & 0.69 & 1.56 & 0.000 & 0.85 & 1.53 & 0.000 \\
\hline $\begin{array}{l}\text { Use instructions } \\
\text { (Score: } 0-3)\end{array}$ & 2.80 & 2.52 & 0.001 & 2.83 & 2.78 & 0.870 \\
\hline $\begin{array}{l}\text { Possible side effects } \\
\text { (Score: } 0-2)\end{array}$ & 0.97 & 1.76 & 0.000 & 1.35 & 1.71 & 0.001 \\
\hline $\begin{array}{l}\text { Alarm signs } \\
\text { (Score: } 0-1)\end{array}$ & 0.29 & 0.70 & 0.000 & 0.57 & 0.66 & 0.185 \\
\hline $\begin{array}{l}\text { Follow-up } \\
\text { (Score: } 0-3)\end{array}$ & 1.75 & 2.34 & 0.000 & 1.95 & 1.93 & 0.504 \\
\hline $\begin{array}{l}\text { General satisfaction } \\
\text { (Score: } 0-2)\end{array}$ & 1.86 & 1.82 & 0.343 & 1.79 & 1.87 & 0.101 \\
\hline $\begin{array}{l}\text { Total } \\
\text { (crnra- } \mathrm{n}-\text { ग) }\end{array}$ & 16.47 & $19.31^{*}$ & 0.000 & 16.34 & $18.42^{*}$ & 0.000 \\
\hline
\end{tabular}


interactions in all sites. Moreover, comparing both groups after the intervention shows that there was a significantly greater improvement in the experimental group than in the comparison group. This additional improvement in the CPI scores in the experimental sites suggests that the study interventions (i.e. the YSP programme) had an impact on CPI over and above that of the readiness interventions.

Among the individual indicators ${ }^{2}$, only three (interpersonal relations, general satisfaction and client's need diagnosis) did not improve in the experimental group. This is probably because scores for interpersonal relations and general satisfaction were already very high and did not improve further within each study group. Both indicators are well known to be liable to courtesy bias, which could explain the consistently high scores. The lack of change in the diagnosis of client's needs indicates that this is the aspect of client provider interactions that needs more attention in the future.

\section{Client load}

Service statistics for twelve continuous months preceding the surveys were compiled for family planning and other services to assess whether the interventions have had any impact on the client load.

Data were obtained from HMIS monthly summary reports, but as can be seen, not all clinics had complete statistics for 12 successive months. These measures assess whether clinics became more attractive as a result of the interventions introduced.

As can be seen on Table 16, clinic attendance increased for all types of services and in both experimental and comparison groups, the exception being in

2 The internal consistency of the scale was assessed using the alpha score, which overall showed a positive correlation for the nine indicators used to construct the scale, indicating good internal consistency. The alpha values for individual indicators showed wide variations within and between the groups, however, indicating various degrees of correlation. The 'general satisfaction' and 'method choice' indicators scored negative alpha values for both experimental and comparison groups, implying that the items from which these indicators were derived were not positively correlated. This in turn suggests that the items may not be appropriate for measuring these indicators. 
experimental clinics where post-natal and STD clinic attendances declined slightly. However, none of these increases were statistically significant, and so any changes noted were not necessarily due to either the readiness or study interventions.

These slight improvements in clinic attendance for all services could be due to the abolition of cost sharing, which occurred in 2001 while the interventions were being introduced. However, since FP services were free even before cost sharing was abolished, the slight increases in FP clinic attendance could be attributed to perceived better quality of services or other factors that the study did not assess.

\section{Conclusions and recommendations}

This study was designed to test the ability of a series of interventions to achieve two outcomes: 1) bring clinics in both experimental and comparison groups to a better and comparable level of "readiness" to offer basic FP services by implementing seven related interventions; and 2) implement three additional study interventions, through the Yellow Star Programme, in the experimental clinics only that would improve the quality of CPI, provider motivation and client load.

The findings showed that the readiness interventions did not significantly improve most aspects of clinic and provider readiness and all clinics were upgraded at comparable functional levels. Supportive supervision improved primarily in the experimental clinics and most supervisors were oriented on and supplied with the supervision guidelines. The interventions did significantly improve provider knowledge of common contraceptives in the experimental clinics, but conversely reduced levels of provider knowledge were found in the comparison clinics. However, levels of knowledge remained worryingly low, which suggests that this aspect of training was inadequate and needs close attention to ensure that clients can have an informed choice of method. However, providers in the experimental clinics improved significantly their ability to obtain information from family planning clients.

Providers' time use patterns did not change as a result of the interventions, although time spent with family planning clients increased slightly in the experimental clinics. The extra time spent with clients was apparently drawn from "unproductive" time and therefore did not impinge on the time available for other services, and so it is clear that providers do not need additional time to improve the quality of care or to see more clients. A worrying observation was that providers spent up to one-third of their time away from clinic work.

Encouragingly, provider job satisfaction improved significantly in both experimental and comparison clinics, and satisfaction among providers in experimental clinics improved more than those in comparison clinics. Better job satisfaction was used as an indirect measure of provider motivation, and this is expected to improve yet further when facilities/providers start receiving the Yellow Star award, which was still in its infancy during the study period.

Challenges identified during implementing the readiness interventions included: creating a unified system of supervision from the many approaches and tools introduced; sustaining 
Quality Assurance (QA) at the district level and cascading QA approaches to facility and community level; and strengthening the supervisory system and supervision skills at all levels to improve compliance with standards.

Implementing the package of study interventions to increase provider motivation, capacity to plan, and client empowerment was expected to result in significantly better quality of family planning CPI and client load. The findings indicate that overall quality of CPI did improve significantly in the experimental clinics. Although CPI also improved in the comparison clinics, the level achieved after introducing both readiness and study interventions was significantly higher in the experimental sites where the study interventions (i.e. the Yellow Star Programme) had also been introduced.

With improved clinic readiness, and better-motivated and more competent providers offering quality services, all clinics were expected to attract more clients, with the experimental group expected to show a greater increase than the comparison group. Although not statistically significant, the study did show an increase in clinic attendance in all sites and for all services, and especially family planning. Comparison clinics registered a proportionately larger increase in client load for new FP clients than the experimental clinics, suggesting that the increase in new FP clients was probably unrelated to the study interventions. Possible explanations for this increase in family planning client load include better availability of FP commodities and possibly higher client satisfaction.

The study has provided empirical evidence that quality of CPI and provider motivation can be improved through a series of provider, clinic and system level improvements. However, the study findings pose further questions including: 1) why do providers spend a large portion of their time on unproductive activities, and what can be done to ensure that providers spend more time serving clients in the health facilities, and 2) how can provider motivation and improved quality of care be sustained in a cost-effective manner?

Drawing from these conclusions, the following recommendations can be made to the Uganda Ministry of Health and its partners concerning activities that seek to improve the quality of family planning services:

- The strategy to distribute the revised RH standards and guidelines and the revised HMIS needs to be improved to ensure that the end-users of these documents (i.e. all providers in the clinics) are oriented in their use and are competently using them.

- $\quad$ The $\mathrm{MOH}$ at the national and district level must enforce in-service training to drastically improve and sustain provider knowledge and competence in providing a range of family planning methods. However, the approach used in this study was not particularly effective, and so a more appropriate and effective training method is needed.

- The study revealed a rather uneconomical use of time by providers when they are officially on duty. The MOH should conduct further research to understand the underlying reasons for frequent provider absence during working hours and late reporting for duty in the mornings, and to determine what could be done to alleviate this problem. 
- The successful scaling up of the Yellow Star Programme will require the MOH and district health services to gather cost data to guide the implementation of the programme.

\section{References}

Bessinger R, Katende C, \& C Lettenmeier, 2000. Uganda Quality of Care Survey of Family Planning and Antenatal Care Services, Carolina Population Centre, North Carolina, USA: Delivery of Improved Services for Health (DISH), Pathfinder International and Measure Evaluation Project

Bruce J, 1990. "Fundamental Elements of Quality of Care: A Simple Framework" Studies in Family Planning, (21): 61-91

Uganda Bureau of Statistics and ORC Macro. 2001. Uganda Demographic and Health Survey 2000-2001, Calverton, Maryland, USA: UBOS and ORC Macro. 


\section{Annex I: Infrastructure, staffing and functions of HC III \& IV}

\begin{tabular}{|c|c|c|c|}
\hline HC III & & & \\
\hline Infrastructure & Minimum staffing & Location & Services \\
\hline $\begin{array}{l}\text { OPD } \\
\text { In-patient wards }\end{array}$ & $\begin{array}{l}\text { Clinical officer } \\
\text { Midwives } \\
\text { Nurses } \\
\text { Nursing assistants } \\
\text { Records clerk }\end{array}$ & $\begin{array}{l}\text { Sub-county, serving } \\
\text { approx } 20,000 \text { people }\end{array}$ & $\begin{array}{l}\text { Curative } \\
\text { Preventive } \\
\text { Promotion } \\
\text { Supervises lower } \\
\text { level facilities } \\
\text { Referrals to higher } \\
\text { level units }\end{array}$ \\
\hline HC IV & & & \\
\hline Infrastructure & Minimum staffing & Location & Services \\
\hline $\begin{array}{l}\text { OPD } \\
\text { In-patient wards } \\
\text { Operating theatre }\end{array}$ & $\begin{array}{l}\text { Medical Officer } \\
\text { Clinical officer } \\
\text { Anaesthetist } \\
\text { Midwives } \\
\text { Nurses } \\
\text { Nursing assistants } \\
\text { Records clerk }\end{array}$ & $\begin{array}{l}\text { County, serving approx } \\
100,000 \text { people }\end{array}$ & $\begin{array}{l}\text { Curative } \\
\text { Emergency surgery } \\
\text { Blood transfusion } \\
\text { Preventive } \\
\text { Promotion } \\
\text { Supervises HC III \& } \\
\text { lower level facilities } \\
\text { Referral of clients to } \\
\text { higher level units }\end{array}$ \\
\hline
\end{tabular}

\section{Annex II: Summary of implementation of QOC interventions}

\begin{tabular}{|c|c|c|}
\hline Interventions & Activities & Target \\
\hline \multicolumn{3}{|l|}{ Clinic Readiness } \\
\hline $\begin{array}{l}\text { Updating \& dissemination of } \\
\text { RH policy guidelines \& } \\
\text { service standards }\end{array}$ & $\begin{array}{l}\text { Review of } 1993 \mathrm{RH} \text { guidelines by } \mathrm{MOH} \\
\text { working group } \\
\text { Circulation of draft to stakeholders for } \\
\text { comments } \\
\text { Dissemination } \\
\text { - Stakeholders meeting } \\
\text { - RH update/refresher trainings } \\
\text { - Distribution to health facilities }\end{array}$ & $\begin{array}{l}\text { District Health } \\
\text { Management } \\
\text { Teams, } \\
\text { Development } \\
\text { partners } \\
\text { NGOs } \\
\text { Service providers }\end{array}$ \\
\hline $\begin{array}{l}\text { Ensuring availability of } \\
\text { minimum equipment } \& \\
\text { supplies required to offer } \\
\text { Depo Provera, pills, and } \\
\text { condoms }\end{array}$ & $\begin{array}{l}\text { Facility inventory } \\
\text { Procurement \& distribution of equipment } \\
\text { Quarterly distribution of contraceptives to } \\
\text { study districts }\end{array}$ & Study clinics \\
\hline Improving clinic environment & $\begin{array}{l}\text { Facility inventory } \\
\text { Procurement \& distribution of furniture } \\
\text { - Examination couches } \\
\text { - Cupboards } \\
\text { - Benches } \\
\text { - Chairs } \\
\text { - Consultation tables }\end{array}$ & Study clinics \\
\hline Improving HMIS & $\begin{array}{l}\text { Training update using the old HMIS } \\
\text { Review of existing HMIS } \\
\text { Dissemination of revised HMIS }\end{array}$ & $\begin{array}{l}\text { District HMIS focal } \\
\text { persons }\end{array}$ \\
\hline
\end{tabular}




\begin{tabular}{|c|c|c|}
\hline & $\begin{array}{l}\text { Computerization of revised HMIS } \\
\text { Procurement of HMIS supplies } \\
\text { Training of providers in data management \& } \\
\text { utilization } \\
\text { Training providers in records keeping and } \\
\text { drug quantification } \\
\text { Upgrading stores }\end{array}$ & $\begin{array}{l}\text { Surveillance } \\
\text { persons }\end{array}$ \\
\hline $\begin{array}{l}\text { Improving availability of } \\
\text { appropriate FP IEC materials }\end{array}$ & $\begin{array}{l}\text { Facility audit } \\
\text { Quarterly printing \& distribution of existing IEC } \\
\text { materials } \\
\text { Production \& distribution of additional IEC } \\
\text { materials } \\
\text { - Yellow Star stickers/posters } \\
\text { - Newsletter }\end{array}$ & Study clinics \\
\hline $\begin{array}{l}\text { Building capacity of } \\
\text { Districts/Sub-districts for } \\
\text { facilitative supervision }\end{array}$ & $\begin{array}{l}\text { Review of existing supervision guidelines by } \\
\text { MOH SWG } \\
\text { Pilot testing draft NSG \& consultation with } \\
\text { stakeholders } \\
\text { Dissemination } \\
\text { - National level } \\
\text { - District level } \\
\text { - Facility level }\end{array}$ & $\begin{array}{l}\text { MOH } \\
\text { Program managers } \\
\text { QAD } \\
\text { Development } \\
\text { partners } \\
\text { DHMTs, } \\
\text { Providers }\end{array}$ \\
\hline $\begin{array}{l}\text { Improving provider } \\
\text { competence }\end{array}$ & $\begin{array}{l}\text { Update/refresher training } \\
\text { Training of unqualified providers } \\
\text { On-job training during supportive supervision }\end{array}$ & $\begin{array}{l}\text { In-service qualified } \\
\text { providers } \\
\text { Nurse-aides } \\
\text { All providers }\end{array}$ \\
\hline
\end{tabular}

Study interventions

Building capacity of DHMTs \& SDHMTs for strategic planning and goal setting

Improving provider motivation

Increasing clients awareness of and demand for quality services
Establishing basic standards (goal setting) for quality of health care

Communicating the standards to the community and health care system:

- Designing the quality symbol (logo)

- Sensitisation of community \& health professionals

- Provider campaigns

- Community campaign (Clients' awareness)

Monitoring \& certifying facilities that met and maintained basic standards (motivation)

\section{Community leaders,} $\mathrm{MOH}$,

DHMTs,

Local governments Operational level providers Clients \& potential clients of study clinics 


\section{ANNEX III: Basic Standards for Quality of Care in the Yellow Star Programme}

\section{Infrastructure and Equipment}

\begin{tabular}{|c|c|c|c|}
\hline \# & Standard & Operational Definition & Means of Verification \\
\hline 1.1 & $\begin{array}{l}\text { Is there a reliable and clean supply of water } \\
\text { from a protected water source? }\end{array}$ & $\begin{array}{l}\text { There is running water (pipe) within the facility, } \\
\text { OR there is a water tank within the facility, } \\
\text { OR there is a protected water source within } 200 \text { m of the facility: } \\
\text { borehole, water tank or protected spring (with tubing of water for } \\
\text { outflow, concrete slab, drainage and the spring is at least } 33 \mathrm{~m} \\
\text { away from latrines/toilets) \& temporary storage containers (e.g. jerry } \\
\text { cans, or drums). } \\
\text { There is water flowing from this main source. }\end{array}$ & $\begin{array}{l}\text { Observation of the water source and } \\
\text { check if water is flowing from the } \\
\text { source. }\end{array}$ \\
\hline 1.2 & $\begin{array}{l}\text { Does the facility have clean latrines or } \\
\text { toilets? }\end{array}$ & $\begin{array}{l}\text { Latrines or toilets exist within the facility. } \\
\text { Staff and clients have access to at least one latrine or toilet at any } \\
\text { given time and the client's latrine or toilet is not locked. } \\
\text { Toilet bowl is clean and empty/latrine slab is clean. } \\
\text { Soap and water are available at the washing point near the } \\
\text { toilet(s)/latrine(s). }\end{array}$ & Observation of toilets/latrines. \\
\hline 1.3 & $\begin{array}{l}\text { Does the facility have a rubbish pit for } \\
\text { disposal of refuse and medical waste? Does } \\
\text { the unit have a placenta pit }(\mathrm{HC} 3+) \text { ? }\end{array}$ & 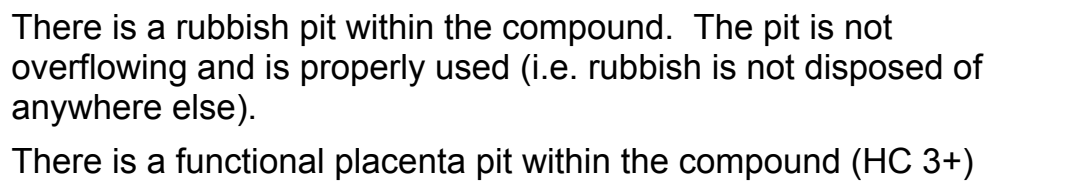 & $\begin{array}{l}\text { Observation of rubbish pit and } \\
\text { placenta pit. }\end{array}$ \\
\hline 1.4 & $\begin{array}{l}\text { Does the facility have a functional } \\
\text { examination couch? (For a facility carrying } \\
\text { out deliveries is there a delivery couch? For } \\
\text { facilities with in-patient wards - are there } \\
\text { beds with mattresses in good shape?) }\end{array}$ & $\begin{array}{l}\text { Examination couch (and delivery couch, in facilities carrying out } \\
\text { deliveries) is present in unit. } \\
\text { It is padded or has some soft material on it covered with mackintosh } \\
\text { or a plastic sheet. It is clean. } \\
\text { (For facilities with in-patient wards: Beds with mattresses are } \\
\text { present in the unit. Mattresses are clean and in acceptable shape.) }\end{array}$ & $\begin{array}{l}\text { Inspection of examination (and } \\
\text { delivery couch and in-patient beds if } \\
\text { applicable) }\end{array}$ \\
\hline
\end{tabular}




\begin{tabular}{|c|c|c|c|}
\hline 1.5 & $\begin{array}{l}\text { Does the facility have basic examination } \\
\text { equipment? }\end{array}$ & $\begin{array}{l}\text { The following pieces of equipment are available, functional and } \\
\text { registered in the inventory: } \\
\text { HC 2: thermometer, baby weighing scale, timing device, ORS } \\
\text { corner, fetoscope, BP cuff/machine, stethoscope, adult weighing } \\
\text { scale, lantern, equipment for boiling } \\
\text { HC 3: thermometer, baby weighing scale, timing device, ORS } \\
\text { corner, neonatal weighing scale, fetoscope, BP cuff/machine, } \\
\text { stethoscope, adult weighing scale, speculum, lantern, equipment for } \\
\text { boiling } \\
\text { HC 4+: thermometer, baby weighing scale, timing device, ORS } \\
\text { corner, neonatal weighing scale, fetoscope, BP cuff/machine, } \\
\text { stethoscope, adult weighing scale, speculum, lantern, microscope, } \\
\text { sterilizer/autoclave, anaesthesia machine, C-section sets (2), } \\
\text { Laparotomy sets (2), refrigerator for blood, cross matching } \\
\text { equipment, blood bags } \\
\text { NOTE: thermometer, BP cuff and stethoscope must be in all } \\
\text { functional clinic areas in the unit (OPD, MCH, maternity, in-patient } \\
\text { wards) }\end{array}$ & $\begin{array}{l}\text { Review of inventory record. } \\
\text { Observation of items in OPD, MCH, } \\
\text { Maternity or In-patients Wards as } \\
\text { applicable. Inspect each item to see if } \\
\text { functioning properly. }\end{array}$ \\
\hline 1.6 & $\begin{array}{l}\text { Are men's and women's in-patient wards } \\
\text { separated? }\end{array}$ & $\begin{array}{l}\text { Men's beds and women's beds are in separate wards or there are } \\
\text { screens or curtains between men's beds and women's beds on in- } \\
\text { patient wards ( } \mathrm{HC} 4+) \text {. }\end{array}$ & Observation of in-patient wards. \\
\hline
\end{tabular}




\section{Management Systems}

\begin{tabular}{|c|c|c|c|}
\hline \# & Standard & Operational Definition & Means of Verification \\
\hline 2.1 & $\begin{array}{l}\text { Do the client registers exist and are they } \\
\text { well kept and up-to-date? }\end{array}$ & $\begin{array}{l}\text { Registers exist in OPD, ANC and FP clinics/maternity. Information } \\
\text { on patient characteristics (names, sex, age and address - } \\
\text { parish/village), diagnosis and treatment (dosage, times/day, \# of } \\
\text { days) are written in the OPD registers. }\end{array}$ & $\begin{array}{l}\text { Inspection of registers in clinic rooms } \\
\text { for the previous month. }\end{array}$ \\
\hline 2.2. & $\begin{array}{l}\text { Were monthly Summary Report forms } \\
\text { completed appropriately over the last } 3 \\
\text { months? }\end{array}$ & $\begin{array}{l}\text { Copy of the HMIS } 105 \text { forms for the last three months is present in } \\
\text { the unit or the information is registered in the unit's database. } \\
\text { The number of reported malaria visits for all ages corresponds to } \\
\text { the number of cases in the OPD register(s) for the same month } \\
\text { (plus or minus } 5 \% \text { ). }\end{array}$ & $\begin{array}{l}\text { Review copies of HMIS } 105 \text { or unit } \\
\text { database. Compare number of } \\
\text { malaria cases with register(s); totals } \\
\text { should be the same. }\end{array}$ \\
\hline 2.3. & $\begin{array}{l}\text { Are there updated stock cards at the facility } \\
\text { store (register books) for at least five } \\
\text { randomly selected products? }\end{array}$ & $\begin{array}{l}\text { Stock cards/register books at the facility store for the five selected } \\
\text { products are present in the store. } \\
\text { Stock cards are up to date and correspond to physical stock. }\end{array}$ & $\begin{array}{l}\text { Randomly choose five drugs from the } \\
\text { list of essential drugs. Review } \\
\text { availability of stock cards. Compare } \\
\text { registered quantities with physical } \\
\text { count at the facility store. }\end{array}$ \\
\hline 2.4 . & $\begin{array}{l}\text { Were the following drugs/contraceptives } \\
\text { available during the past } 3 \text { months at the } \\
\text { facility: chloroquine, cotrimoxazole, ORS, } \\
\text { measles vaccine, DPT vaccine, Depo- } \\
\text { Provera and condoms? }\end{array}$ & $\begin{array}{l}\text { Stock cards show the absence of a stock out for the mentioned } \\
\text { drugs/contraceptives for the past three months. }\end{array}$ & Review of stock cards/register books. \\
\hline 2.5 . & $\begin{array}{l}\text { Does the Health Unit Management } \\
\text { Committee meet once every quarter? }\end{array}$ & $\begin{array}{l}\text { Minutes of meetings conducted during the last quarter are available } \\
\text { at the facility. }\end{array}$ & Review of meeting minutes. \\
\hline 2.6 & $\begin{array}{l}\text { Does the facility have the guidelines and } \\
\text { standards required for management of } \\
\text { clients/patients? }\end{array}$ & $\begin{array}{l}\text { National Standard Treatment Guidelines and IMCI Treatment } \\
\text { Guidelines are available in the consulting room(s). }\end{array}$ & $\begin{array}{l}\text { Verify availability of both documents in } \\
\text { the consulting room and make sure } \\
\text { they are accessible. }\end{array}$ \\
\hline
\end{tabular}




\section{Infection Prevention}

\begin{tabular}{|c|c|c|c|}
\hline \# & Standard & Operational Definition & Means of Verification \\
\hline 3.1. & $\begin{array}{l}\text { Does the facility provide adequate infection } \\
\text { prevention/control in the area of hand } \\
\text { washing? }\end{array}$ & $\begin{array}{l}\text { Soap and water are available at the washing point(s) in or near the } \\
\text { consulting room(s). } \\
\text { Providers wash their hands between clients and procedures. }\end{array}$ & $\begin{array}{l}\text { Observation of available water and } \\
\text { soap. Observation of provider } \\
\text { practices. }\end{array}$ \\
\hline 3.2. & $\begin{array}{l}\text { Does the facility provide adequate infection } \\
\text { prevention/control in the area of disposal of } \\
\text { sharps and needles? }\end{array}$ & $\begin{array}{l}\text { There are labelled containers for sharp object disposal available in } \\
\text { the examination, injection and dressing rooms. } \\
\text { Staff safely disposes of sharp objects and needles in the container } \\
\text { provided and do not reuse disposable material. }\end{array}$ & $\begin{array}{l}\text { Availability of sharp object containers } \\
\text { in the examination, injection and } \\
\text { dressing rooms. Observation of the } \\
\text { absence of sharps in the rubbish pit, } \\
\text { receivers or in open areas. } \\
\text { Observation of staff practices. }\end{array}$ \\
\hline 3.3. & $\begin{array}{l}\text { Are the injection, dressing and examination } \\
\text { rooms (and delivery/labour room(s) for } \\
\text { facilities with delivery services) clean } \\
\text { service environments? }\end{array}$ & $\begin{array}{l}\text { Dressing room(s), injection room(s) and examination room(s) [and } \\
\text { delivery room(s) where applicable] are swept and free of soiled } \\
\text { materials. } \\
\text { There is a dustbin available in the room. }\end{array}$ & $\begin{array}{l}\text { Observation of rooms and dressing } \\
\text { trolleys. }\end{array}$ \\
\hline 3.4 . & $\begin{array}{l}\text { Does the health unit have facilities for } \\
\text { disinfection and sterilization? }\end{array}$ & $\begin{array}{l}\text { Buckets, chlorine solution (e.g. JIK) and other disinfectants are } \\
\text { available. }\end{array}$ & $\begin{array}{l}\text { Observation of a bucket with } \\
\text { disinfectant prepared. }\end{array}$ \\
\hline 3.5 & $\begin{array}{l}\text { Is the staff following correct aseptic } \\
\text { techniques? }\end{array}$ & $\begin{array}{l}\text { Health workers are performing according to guidelines the following } \\
\text { aseptic procedures: wound dressing, suturing, catheterisation, } \\
\text { injections, Norplant }{ }^{\circledR} \text { insertion or removal, intravenous infusion and } \\
\text { dental extraction. }\end{array}$ & $\begin{array}{l}\text { Observation of three aseptic } \\
\text { procedures. }\end{array}$ \\
\hline
\end{tabular}

\section{IEC/IPC}

\begin{tabular}{|c|c|c|c|}
\hline \# & Standard & Operational Definition & Means of Verification \\
\hline 4.1. & Are health education talks given to clients? & $\begin{array}{l}\text { Health facility conducts group health education sessions at least } 4 \\
\text { times per month for previous } 3 \text { months. }\end{array}$ & $\begin{array}{l}\text { Observe HMIS } 105 \text { summary forms for } \\
\text { previous } 3 \text { months. }\end{array}$ \\
\hline 4.2. & $\begin{array}{l}\text { Do providers use appropriate teaching } \\
\text { aides during client counselling/education? }\end{array}$ & $\begin{array}{l}\text { Service providers use one of the following materials during client } \\
\text { counselling/education sessions: posters, sample foods or family } \\
\text { planning methods, anatomical models, brochures, leaflets, flipcharts } \\
\text { or cue cards. }\end{array}$ & $\begin{array}{l}\text { Observation during provider/client } \\
\text { interactions. }\end{array}$ \\
\hline 4.3. & $\begin{array}{l}\text { Are service providers encouraging clients to } \\
\text { actively discuss any problem or concern } \\
\text { about their health and treatment during the } \\
\text { visit? }\end{array}$ & $\begin{array}{l}\text { Providers ask clients about their history and problems. } \\
\text { Providers invite clients to ask questions. }\end{array}$ & $\begin{array}{l}\text { Observation of interaction with three } \\
\text { clients and/or caretaker from that day. }\end{array}$ \\
\hline
\end{tabular}


Clinical Services

\begin{tabular}{|c|c|c|c|}
\hline \# & Standard & Operational Definition & Means of Verification \\
\hline 5.1 & $\begin{array}{l}\text { Does the staff maintain a proper cold } \\
\text { chain? }\end{array}$ & $\begin{array}{l}\text { For facilities with a refrigerator: Temperature monitoring chart is } \\
\text { fixed on the refrigerator. Temperatures are monitored twice daily, } \\
\text { seven days per week. Temperatures maintained between } 0 \text { and } \\
8^{\circ} \mathrm{C} \text {. } \\
\text { Thermometer is in the refrigerator. } \\
\text { For all facilities: vaccine carriers and ice packs available and in } \\
\text { good condition }\end{array}$ & $\begin{array}{l}\text { Observation of temperature chart, } \\
\text { refrigerator (if present in the unit), ice } \\
\text { packs and vaccine carriers. }\end{array}$ \\
\hline 5.2. & $\begin{array}{l}\text { Are immunization services provided on a } \\
\text { daily basis in this facility so as to reduce } \\
\text { "missed opportunities"? }\end{array}$ & $\begin{array}{l}\text { Staff reviews health card of each child and checks the immunization } \\
\text { status of all under-five children coming to the facility. } \\
\text { For facilities with a refrigerator, staff provides immunization to the } \\
\text { child during the same day/visit. } \\
\text { For facilities without a refrigerator, staff provides at least weekly } \\
\text { immunization services. }\end{array}$ & $\begin{array}{l}\text { Review records, tally sheets and } \\
\text { immunization registers for dates. }\end{array}$ \\
\hline 5.3. & $\begin{array}{l}\text { Do all the children who visit the facility } \\
\text { have their weight plotted correctly on the } \\
\text { health card? }\end{array}$ & $\begin{array}{l}\text { The under-five children coming to the facility are weighed. } \\
\text { Weight is accurately plotted on the child's health card. } \\
\text { A line is drawn to connect the dots. }\end{array}$ & $\begin{array}{l}\text { Review child health card of three } \\
\text { children exiting the consulting room(s) } \\
\text { to see if weight is accurately plotted. }\end{array}$ \\
\hline 5.4. & $\begin{array}{l}\text { Are providers giving technically appropriate } \\
\text { services? }\end{array}$ & $\begin{array}{l}\text { Health workers are providing technically correct services, according } \\
\text { to current guidelines and supervision checklists in the following } \\
\text { areas: IMCI, ANC, Delivery, PNC, FP, STD, Malaria., TB, Injury } \\
\text { management, Dental care }\end{array}$ & $\begin{array}{l}\text { Observation of three cases in any of } \\
\text { the mentioned areas and assessment } \\
\text { of the adequacy of case management } \\
\text { based upon the compliance with the } \\
\text { checklists included in the NSG }\end{array}$ \\
\hline 5.5 & $\begin{array}{l}\text { Are providers giving technically appropriate } \\
\text { inpatient care? }\end{array}$ & $\begin{array}{l}\text { Health workers are providing correct treatment (review diagnosis, } \\
\text { treatment, timing of medication) according to National Supervision } \\
\text { Treatment Guidelines for the following in-patients: sick children, } \\
\text { medical and surgical. }\end{array}$ & $\begin{array}{l}\text { Review medical records (registers, } \\
\text { treatment cards) of three clients and } \\
\text { interview in-patients/caretakers about } \\
\text { his/her diagnosis and treatment. }\end{array}$ \\
\hline
\end{tabular}


Customer Services

\begin{tabular}{|c|c|c|c|}
\hline$\#$ & Standard & Operational Definition & Means of Verification \\
\hline 6.1. & $\begin{array}{l}\text { Is the facility's waiting area clean and } \\
\text { protected? }\end{array}$ & $\begin{array}{l}\text { The waiting area protects clients from the sun and rain. } \\
\text { The floor is swept or mopped. The area is clean of debris/trash. }\end{array}$ & Observation of waiting area(s). \\
\hline 6.2 . & $\begin{array}{l}\text { Does the facility have a private area for } \\
\text { physical examinations and/or deliveries? }\end{array}$ & $\begin{array}{l}\text { Examination areas are either private rooms with doors that close or } \\
\text { areas sectioned off by curtains/screens. } \\
\text { Privacy is maintained during procedures }\end{array}$ & $\begin{array}{l}\text { Observation of all examination rooms. } \\
\text { Observation of provider practices. }\end{array}$ \\
\hline 6.3. & $\begin{array}{l}\text { Are patients and their attendants received } \\
\text { in friendly and respectful manner? }\end{array}$ & $\begin{array}{l}\text { Clients answer yes to the following questions: } \\
\text { Did the health worker direct you where to go next? } \\
\text { Did you feel you were treated respectfully by the health worker(s) } \\
\text { who you met at the health facility today? [I NO, note why.] }\end{array}$ & Exit interviews with three clients. \\
\hline 6.4 . & $\begin{array}{l}\text { Do providers see clients on first-come, } \\
\text { first-serve basis? }\end{array}$ & $\begin{array}{l}\text { There is a system in place to serve clients in the order in which they } \\
\text { arrive. Only the extremely sick are given priority. }\end{array}$ & Observe clients' flow. Interview providers. \\
\hline 6.5. & $\begin{array}{l}\text { Do clients wait one hour or less after } \\
\text { arrival at the facility before being seen by a } \\
\text { provider? }\end{array}$ & $\begin{array}{l}\text { Clients state that they were seen in one hour or less from the time } \\
\text { he/she entered the facility for non-emergency cases. }\end{array}$ & Exit interviews with three clients. \\
\hline 6.6 & $\begin{array}{l}\text { Does provider/dispenser provide } \\
\text { appropriate information to client regarding } \\
\text { treatment compliance? }\end{array}$ & $\begin{array}{l}\text { Provider/dispenser instructs clients about the medication, the } \\
\text { amount of medication to take, what time of the day it should be } \\
\text { taken and for how long it should be taken. } \\
\text { Provider/Dispenser checks the client's understanding. }\end{array}$ & $\begin{array}{l}\text { Observation of three clients receiving } \\
\text { treatment at the dispenser's window (or } \\
\text { from the provider if there is no dispenser). }\end{array}$ \\
\hline 6.7 . & $\begin{array}{l}\text { Does the facility have a plan for referring } \\
\text { emergency cases? }\end{array}$ & $\begin{array}{l}\text { The facility provides some type of assistance for moving a sick } \\
\text { patient to a referral facility, such as: communication to the next } \\
\text { level, ambulance, arranging community transport, or funds for fuel } \\
\text { or public transport. }\end{array}$ & $\begin{array}{l}\text { Interview with the in-charge and one other } \\
\text { provider. }\end{array}$ \\
\hline 6.8. & $\begin{array}{l}\text { Does the facility have at least one staff } \\
\text { member trained in the following areas in } \\
\text { the OPD and MCH departments: IMCI, FP, } \\
\text { STD management, ANC/PNC, and Malaria } \\
\text { management? }\end{array}$ & $\begin{array}{l}\text { The facility has at least one provider offering these services to } \\
\text { clients who has received in-service training specific to these } \\
\text { services: IMCI, Family Planning, STD management, ANC/PNC and } \\
\text { Malaria Management. }\end{array}$ & $\begin{array}{l}\text { Interview with in-charge and } \mathrm{MCH} / \mathrm{OPD} \\
\text { providers on site. Cross check information } \\
\text { with DDHS office }\end{array}$ \\
\hline 6.9. & $\begin{array}{l}\text { Does the facility post a list of available } \\
\text { services where the clients can see them? }\end{array}$ & $\begin{array}{l}\text { A poster with listed services is displayed in the waiting area where } \\
\text { the clients can see it. }\end{array}$ & Observation of waiting area. \\
\hline 6.10 & $\begin{array}{l}\text { Is there a health provider available at all } \\
\text { times? }\end{array}$ & $\begin{array}{l}\text { A qualified health provider is available } 24 \text { hours a day, } 7 \text { days a } \\
\text { week ( } A \text { qualified provider = nurse, midwife, CO or MO) for HC3+. } \\
\text { There is staff housing near the health facility OR in the unit, a duty } \\
\text { room is available for staff with sleeping accommodations. }\end{array}$ & $\begin{array}{l}\text { Review the current duty roster. } \\
\text { Observation of staff housing or duty room } \\
\text { with sleeping accommodations. }\end{array}$ \\
\hline
\end{tabular}

